\title{
A Sociological Approach to the Russian Constitution
}

\author{
Maria Smirnova \\ Research Associate in Russian Constitutional Law, \\ University of Manchester, UK \\ maria.smirnova@manchester.ac.uk \\ Chris Thornhill \\ Professor of Law, University of Manchester, UK \\ chris.thornhill@manchester.ac.uk
}

\begin{abstract}
This article promotes a distinctive sociological interpretation of the Russian Constitution. Much literature on Russian constitutional law is defined by the claim that the Constitution has little factual reality and limited foundation in society. This article challenges this view on two grounds. It argues that there are two deep-lying social processes that underlie the Constitution, and condition its evolution: the Constitution is shaped (a) by the importance of constitutional law for the stabilization of governance structures; (b) by the resultant relative autonomy of judicial practices, which means that legal exchanges (especially litigation) have formative impact on the constitutional order. On both grounds, the Russian Constitution is locked into cycles of societal norm construction. To understand the sociological linkages in which the constitution is located, we require a complex construction of society, and we need to observe how different practices within the legal system affect and even produce constitutional laws.
\end{abstract}

\section{Keywords}

sociology of constitutional law - Russian constitution - judicial politics - litigation 
This article is intended to promote a distinctive sociological interpretation of the Russian constitution. To this end, it builds on a body of recent sociological literature on constitutionalism, which examines different national constitutions, not only as formal-legal constructions, but as products of deep-lying social and historical or evolutionary trajectories, which contribute to the wider stabilization and reproduction of society as a whole (see Thornhill 2011:10; 2016: 1-30). In particular, it utilizes the insight in this literature that constitutional law is often formed by contingent processes, deeply embedded in the structure of a given society, and the acts that give rise to constitutional law often occur outside the realm of conventional constitutional practice and beyond the classical categories of constituent subject. Sociological methods are not widely used in discussions of Russian constitutional law. In fact, recent analyses have reflected on the absence of sociological inquiry in Russian constitutionalism (see Andreeva 2013: 113). Nonetheless, the last few years have seen some tentative attempts to apply sociological perspectives to Russian constitutional law. ${ }^{1}$ This article is intended to contribute to these debates, offering a particular sociological paradigm for explaining the Russian constitution and its formation.

The development of sociological methods to explain Russian constitutional law has been partly impeded by standard positions in more conventional accounts of the Russian constitution. Indeed, the reasons why the Russian Constitution is not exposed to sociological analysis are not hard to find. Most typically, for example, studies of the Russian Constitution focus on classical questions of constitutional legitimacy and design, and they usually stress the deficiencies of the Russian constitution, especially in the distribution of power between branches of government (Remington 2000: 499-520; MorganJones 2010: 151; Robertson 2011: 109). One common presumption in research on this topic, further, is that the Russian constitution is located in a sphere that is far removed from meaningful reality, ${ }^{2}$ and its importance as a fixed

1 Some of the Russian literature has called for more extensive use of sociological inquiry in Russian constitutional law (see Levakin 2016: 17). One leading researcher engages extensively with recent research outside Russia in constitutional sociology, concluding that: 'Sociological analysis in constitutional law is particularly important in Russia' (see Andreeva 2013: 114). See also related claims in Mitukov (2007: 19-23); Zhukov (2012: 59); Ovsepyan (2013: 22).

2 In Russian literature this idea is explained through the concept of 'constitutional potential' or 'constitutional ideals'. See as examples of this among others Borisov (2002: 195); Dobrynin (2009: 5); Maliy (2014: 616); Shakhray (2014: 83). 
legal order is overshadowed by the informal norms and informal institutions that shape factual interactions in society and in government and condition exchanges between citizens and government agencies. ${ }^{3}$ In fact, many contemporary observers simply deny the importance of formal legal rules as principles with power to determine the political arena (Gelman 2015: 146; Hale 2015: 20). As a consequence, constitutional law usually appears negatively as an object of sociological inquiry, and, like earlier lines of Marxist analysis, sociological research is mainly concerned with explaining the functional split between real law and formal constitutional law (Ovsepyan 2013: 22). Notably, one leading observer adopts a paradigm used originally for analysing the constitutional reality of Germany under the NSDAP, the paradigm of the Doppelstaat, to describe the separation between the formal legal system and the objectively effective, more informal, para-legal or para-constitutional apparatus of government in Russia. ${ }^{4}$ Even sympathetic observers, e.g. Hendley (1999: 92), suggest that Russian constitutional law is not correlated with a strong societal demand for law, and its foundations in society are weak. More generally, moreover, constitutional analysis tends to position the Russian constitution at varying points on an implied spectrum between liberalism and authoritarianism, and it judges the Russian constitution harshly by such criteria, interpreting the dominance of the executive as a sign of the irrelevance of the constitution for

3 See Rose (1995: 41), Pistor (2002: 83). For the most extreme position in this line of analysis, see Ledeneva (2006: 172; 2008: 328). For a broader application of this theory see Hale (2011: 581).

4 See the account of 'practices of para-constitutionalism' in Sakwa (2011: 47). For this claim in nuce, see Sakwa (2010: 185-206). Sakwa begins this analysis by stating (p. 185), in simple terms: 'Contemporary Russian politics can be characterized as a struggle between two systems: the formal constitutional order, what we call the normative state; and a second world of informal relations, factional conflict, and para-constitutional political practices, termed in this article the administrative regime.' Apart from the moral problem of applying Fraenkel's (in itself historically dubious) analysis of Hitler's genocidal quasi-state to Putin's governance system, Sakwa's observations contain some historical absurdities. At one point, he claims (p. 190): 'Germany had a long history of robust constitutionalism, whereas Russia lacks a strong constitutional culture, and thus, the rule of law and the independence of the judiciary are at best tenuous.' Russia today surely has a far stronger constitutional tradition than existed in Germany before 1933. Prior to 1933, the German national government, whether in Imperial Germany or the Weimar Republic, had never been consistently constrained by solid constitutional norms, and there was no effective system for protecting the constitution against executive abuse. In the Weimar Republic, many key decisions of political and economic policy had been made under pieces of emergency legislation, based in Art 48 of the Weimar Constitution. Sakwa's approach can be traced to earlier attempts to apply Fraenkel's categories to the legal system of the Soviet era, and it suggests a deep continuity between Stalin's law and Putin's law. See for background Sharlet (1977: 155). 
society as a whole. The unusual relation between political parties and the presidential executive in the Russian polity has acquired a very central position in debates about the constitution (Sakwa 2012: 311). As is widely known, the leading party, United Russia, exists in part to mediate between special interests in the Duma, and it is commonly deployed by the President to balance interfactional antagonisms and to facilitate the passage of legislation (Remington 2008: 984; Makarenko 2012: 63). United Russia thus acts as a political consensus broker for the executive, or as a link in a chain of executive command (Petrone 2011: 174; Roberts 2012: 98). For these reasons, the Russian political system is a quite extreme variant on the dominant-party model of governance. For some observers, such as Reuter (2010: 295), this fact places it outside the established category of constitutional government. ${ }^{5}$ For some observers, moreover, this fact means that Russian constitutional law needs to be perceived as having little foundation in societal practices more widely. Implicitly, therefore, much literature on the Russian constitution suggests that Russian constitutional law is ill-suited as an object for sociological inquiry, and it is not supported by the deep-lying motivations for compliance, which, at least in classical legal sociology, are seen as necessary to underpin and to legitimate constitutional norms (Weber 1921: 124).

In contrast to such perspectives, this article proposes an approach to the Russian constitution which insists that, in certain decisive ways, it can be interpreted as a societal construction, standing at the intersection of a number of formative societal pressures and interactions, and it does not occupy a reality that is abstractly separated from social practice or social expectations more broadly. This article proceeds from the claim that the Russian constitution should not be observed, solely, either as a simple institutional arrangement or as an irrelevant legal abstraction. On the contrary, it should be seen as a shifting body of objective norms, shaped by a mass of factual processes and practices, each of which has certain normative implications, some of which pull in opposing directions, and which, in total, can only be understood through multi-level sociological analysis. In this respect, this article seeks to place the Russian constitution back in society. To be sure, society does not appear here in its usual form; no claim is made here, for example, that the constitution is immediately enacted and legitimated by society in the form of

5 See more extreme critique in Hassner (2008: 5-15); Petrone (2011: 168); Chandler (2014: 743); Gill (2015). Amongst grounds for this classification can be included amendments (2004) to the Law on Political Parties (2001), making restrictive provisions for the formation of political parties. The source of legislation quoted in this article, unless otherwise noted, is www.pravo .ru and www.consultant.ru. 
a unified popular subject or an aggregate of citizens, engaged in common patterns of political participation, or marked by common political motivations, as asserted, inter alia, by Habermas (1962) and Loughlin (2010: 157). In fact, one reason why legal research has undervalued the societal aspect of Russian constitutional law is that it typically employs a simplified model of society, imagining, in the wake of Weber, that constitutions acquire their social foundations through rather stylized subjectivistic patterns of collective motivation. In contrast, it is argued here that the societal dimension of the Russian constitution needs to be observed in a more nuanced micro-sociological perspective. In particular, it is claimed that the social basis of the constitution can be observed in a multitude of functional exchanges and communications, many of which occur outside more conventional concepts of political engagement, but which nonetheless deeply shape the form of constitutional law. Often, these communications occur within the legal system itself, such that acts of interpretation, legal formulation, and, above all, litigation, can be observed as vital constitutional practices.

On this basis, this article proposes the concept of secondary constitutionalization, describing a broad range of legally formative social actions and functions, to capture the ways in which social practices contribute to the construction of real constitutional law in Russia. ${ }^{6}$ Naturally, most constitutions are first created through primary constitution-making acts, which involve the textual drafting, ratification, and enforcement of written constitutions. However, some constitutions then gain enhanced purchase through subsequent processes of secondary constitutionalization: that is, through a range of societally embedded practices, some politically ordained, others more freely determined, in which the text of the Constitution is expanded through acts of interpretation, selective implementation, and norm-forming actions (especially litigation), and the reach of constitutional law into society is intensified. Although primary constitution making is usually a formally controlled process, in the dimension of secondary constitutionalization constitutions are shaped by complex sociological

6 The sociological idea underlying this theory is based in the claim that constitutional norms form a nexus between the political system and the legal system, and they act to translate political authority into a form that is adapted to the social terrains to which it is applied. Contrary to the originally Weberian constitutionalist argument that constitutions create, and then presuppose, motivational compliance for the political system in society, it is argued here that constitutional norms allow the political system cognitively to adapt to its environments, and constitutional law necessarily acquires a certain independence in defining the normative form in which political power is applied in society. See for one sociological theorization of this view Luhmann (1980: 261; 1993: 424). 
forces, and they can easily follow partly self-directed adaptive pathways. In its secondary dimension, constitutional law can be elaborated by a variety of actors, and through many patterns of norm construction and institution building, and it typically responds to multiple societal demands for constitutional principles. Moreover, once a particular mode of secondary constitutional construction has commenced, it is not easy to steer, or to stop.

This distinction between primary and secondary constitutionalization is especially relevant for examinations of Russian constitutional law. Since 1993, a political system has evolved in Russia whose constitution possesses a number of atypical features, which generates support for the government in rather unusual fashion, ${ }^{7}$ and which places the exercise of governmental authority in a distinctive accountability regime. However, the evolution of this constitutional setting has been driven, not solely by reflected constitution-making acts, but also by a variety of secondary processes and practices, partly shaped by the unusual circumstances that form the societal environment of the political system. To some degree, as in other countries, ${ }^{8}$ secondary constitutionalization is an inevitable part of Russian constitutional law. In its purely textual form, ${ }^{9}$ in fact, the Russian Constitution of 1993 was designed to put into effect a strategy of broad-ranging social reconstruction (see Komarova 2014: 5), and its material realization was seen to presuppose a sequence of secondary legislative procedures. Accordingly, post-1993 constitutional doctrine in Russia has been widely informed by a quasi-teleological theory of aspirational constitutionalism. This theory defines the public rights and public duties enunciated in the constitution as inchoate goods, which need to be secured in society through subsequent implementation (Shakhrai 2013), notably through measures to improve judicial performance and consistency. ${ }^{10}$ Beyond the intentional level, however, the Russian constitution has also developed through a number of more diffuse, societalized secondary processes. In its material form, the Russian constitution now possesses a functional reality which is partly separate from the formal expectations set out in the original text, and whose

7 Throughout the text the term 'government' is used as a synonym of the state power. To refer to the executive branch of the state power in Russia we use the term the Government of the Russian Federation.

8 See the classic doctrinal variant in this process in Canada, in Henrietta Muir Edwards and others (Appeal No. 121 of 1928) v The Attorney General of Canada (Canada) [1929] U KPC 86 (18 October 1929). The concept of secondary constitutionalization is applied here to Russia, not only as a doctrinal concept, but as a description of a sociological process. The Constitution of the Russian Federation. Adopted by the national referendum on 12 December 1993.

$10 \quad$ See below pp. $75^{6-57}$. 
foundations are diffusely linked to independent patterns of agency and modes of legal practice in Russian society.

One primary benefit of an approach focusing on secondary constitutionalization is that it interprets constitutions in a complex perspective, and it sees constitutions as marked by radial linkage to many deep-lying processes in society. A further benefit of this approach, accordingly, is that it observes society itself in a complex perspective, and it sees society, not as a simply delineated social space, but as multiple domains of action, containing multiple demands for law, which assume relevance for constitutional law in quite different ways. ${ }^{11}$ In each respect, this approach opens a distinctive legal-sociological framework for the interpretation of Russian constitutional law. Using this perspective, we argue that debate about Russian constitutionalism needs to be directed away from simplified classifications of the Russian political system. In approaching the Russian political system, it is necessary to abandon the categorical dichotomy between liberalism and authoritarianism, which underpins much research on processes of regime change in Russia since the dissolution of the Soviet Union. This dichotomy has serious analytical flaws, not only when applied to Russia. It tends to lead to the positing of excessively stark antitheses between political systems of different kinds, ${ }^{12}$ and it obscures the fact that, not only in Russia, seemingly liberal policies sometimes have seemingly authoritarian consequences, and vice versa. Instead, we need to view the Russian constitution, in its societal context, as a legal order that generates very atypical, yet not insubstantial, accountability structures.

The Russian Constitution and its Social Foundations: Constitutionalism and State Fracture

It is essential to note, first, that the existing form of the Russian constitution has been defined by very unusual historical conjunctures. These conjunctures are of vital importance for explaining the sociological basis of the constitution. Obviously, the Constitution, in the formal sense, was written and put into effect in the early 1990s, and it reflects the particular balance of institutional forces (i.e. a weak Parliament and a strong President) at that point (see Smith 1996: 97). However, it was constructed as an elaborated social form

\footnotetext{
11 This approach fundamentally disputes the claim that there is limited demand for law in Russia. See Pistor (2002: 83).

12 Close to this view, see Carothers (2002: 14); Levitsky and Way (2002: 53). On Russia in particular, see Shleifer and Treisman (2005: 163).
} 
through a series of subsequent developments, initiated mainly during the presidency of Vladimir Putin. Much of the current constitutional system only became an objectively meaningful social reality under Putin, reflecting conditions that accompanied the early part of Putin's presidency.

In this respect, most notably, the current constitutional order is strongly determined by the fact that Putin inherited a state structure which had been brought close to implosion under the government of Boris Yeltsin. To be sure, before the late 1980s, the government of the Soviet Union had often veered towards extreme weakness, and its historical reliance on dense patrimonial interlinkage between public actors and private elites, especially in remote regions (Walker 2003: 30), clearly unsettled the basic structure of the political system (McFaul 1995: 221; Easter 1996: 551-578; Garcelon 2005: 51). However, the debility of the Russian state was acutely intensified during Yeltsin's presidency. On one hand, state structure was eroded under Yeltsin by a process of state capture or office and resource grabbing by economic elites, as a result of which, during the 199os, public institutions were partly deformalized, or hollowed out through corruption and private monopolies. ${ }^{13}$ On the other hand, state structure was undermined by the incremental ebbing of authority from the national government to the regions and to regional leadership groups in the Russian Federation. This weakening of the federal centre had actually begun under Gorbachev, whose systemic reforms in the 1980 s had triggered a surge of ethnic centrifugalism (Walker 2003: 6). However, this process became much more destabilizing during Yeltsin's presidency. Originally, in the late 1980 s and early 1990s, Yeltsin encouraged declarations of sovereignty amongst former constituent units of the Soviet Union and, later, of the Russian Federation, ${ }^{14}$ not lastly because this allowed him to obtain allies in his political rivalry with Gorbachev (Kahn 2000: 76). Later, one strategy that sustained Yeltsin's presidency after the passing of the 1993 Constitution was that he entered a series of bilateral treaties with different regions in the federation, and he devolved power, on a contractual basis, to regional rulers in return for (desperately needed) political support. These treaties obviously led to a dispersal of power from the federal centre, and they fragmented the basic structure of the political system.

13 See Shlapentokh (1996: 394, 396); Grzymala-Busse and Luong (2002: 545); Tompson (2002: 933-957); Gelman (2004: 1024); Garcelon (2005: 221); Easter (2008: 602, 6o6); Taylor (2011: 25).

14 The phrase 'parade of sovereignty' is usually used to describe declarations of sovereignty by republics of the Russian Federation and the former ussR. Notably, this culminated in the famous challenge 'take as much sovereignty as you can swallow', issued by Yeltsin in August 1990 to the federal subjects. 
Many subjects of the federation were able to assume semi-autonomous positions within polity as a whole (Konitzer and Wergren 2006: 503; Robertson 2011: 109-110). Moreover, these treaties meant that centre-periphery relations in the Russian Federation became highly asymmetrical, as different treaties were negotiated on very unequal terms. Additionally, these treaties exacerbated already pronounced tendencies towards corruption and patron-client dependencies in regional governance, allowing some governors to build up islands of private influence outside federal control (see Shlapentokh, Levita and Loiberg 1997: 214; Chebankova 2010: 23, 27). The rising arrogation of public authority by private actors then naturally meant that functions, services and transactions usually mediated through the public domain were increasingly secured through informal private interactions. As a result, generally, Yeltsin's period of influence saw a rapid erosion of the public distinction and authority of the central state, it witnessed a haemorrhaging of public confidence in official institutions, and it experienced a precipitous drop in popular compliance with public legal directives. Notably, depletion of state structure impacted in especially deleterious manner on the Russian system of justice, and social agents, increasingly bereft of trust in formal judicial procedures, showed a growing propensity for pursuing justice by informal means (Grzymala-Busse and Luong 2002: 545). For these reasons, on his assumption of the presidency in 1999-2000, Putin was confronted with a catastrophic lack of stateness - that is, with an absence of a reasonably differentiated or autonomous political system - as a primary political problem. In fact, by the late 199os, even the existence of a state in Russia, if statehood is defined in Weberian categories, had become disputable.

This near implosion of public order formed the initial policy-making context for Putin's presidency, and it defined his earlier legislative programmes.

At one level, Putin reacted to these problems by devising strategies of governmental centralization, capacity building, and institutional verticalization. He focused his zeal, in particular, on implementing policies to strengthen the central executive and to weaken the forces, both within and outside the political system, which dragged against governmental (i.e. presidential) authority. Most obviously, in 2001, Putin introduced the law 'On Political Parties,', ${ }^{15}$ which formalized procedures for the creation and registration of parties, and which, although not in itself restrictive, cemented a tighter, more fully nationalized party system, eventually dominated by United Russia (Roberts 2012: 130). Moreover, in the years 2000-2003, Putin introduced a series of laws and measures to elevate the authority of the federal executive over the regions.

15 Federal Law No. 95-FZ of 11 July 2001 'On Political Parties'. 
He accomplished this by dividing the country into macro-regions or federal districts (okrugs), by reforming the procedures for election to the Council of Federation, by claiming control of regional incomes, and by increasing presidential influence in regional political appointments. ${ }^{16} \mathrm{~A}$ key element in these strategies of verticalization was that in 2003 legislation was adopted to weaken the independent force of bilateral treaties between the Federation and its constituent subjects, ${ }^{17}$ and more uniformly to delineate the partition of competence between centre and regions (see Hale 2006: 201; Chebankova 2010: 54-6o). Ultimately, Putin's masterstroke against 'freewheeling decentralization' came in legislation of 2004, ${ }^{18}$ which abolished elections for regional governors and permitted the President to depose governors. ${ }^{19}$

In tandem with these policies, moreover, in 2000, Putin implemented a raft of judicial reforms (already in part foreseen in earlier legislation), which were intended to enhance the uniformity of the rule of law across Russian society, and to impose greater consistency on the national judicial system. ${ }^{20}$ In this

16 President of the Russian Federation Decree No. 849 of 13 May 2000 'On the Plenipotentiary Representative of the President in Federal Districts'.

17 Federal Law No. 95-FZ of 4July 2003 invalidated the previous legislation on bilateral treaties (Federal Law No. 119-FZ of 24 June 1999) and introduced a requirement to legitimize the existing bilateral treaties through their validation by the Duma. Those treaties that failed the validation process became void upon expiry of a two-year transition period.

18 Federal Law No. 184-FZ of 6 October 1999 'On General Principles of Organization of Legislative (Representative) and Executive Bodies of Subjects of the Russian Federation'. For comment see Konitzer (2005: 195, 231).

19 Federal Law No. 159-FZ of 11 December 2004.

20 Some of these laws had been written under Yeltsin, but were put into effect by Putin. Examples of such laws are Code on Administrative Offenses (2001); Criminal Procedure Code (2001); The Federal Law on Mediator Judges (2002); The Federal Law on the Judicial Community (2002); Federal Law on Civil Members of the Jury (2000); Amendments to the Civil Procedure Code (on proceedings concerning protection of electoral rights, challenging normative acts, appeal proceedings for rulings of justices of the peace) (2000); Federal Law on Expert Work in Courts (2001); Amendments to the Criminal Procedure Code regarding consideration of claims by justices of the peace (2000). Laws introducing judicial reforms initiated by Putin include the following: Federal Law on Civil Members of the Jury in Arbitrazh Proceedings (2001); Federal Law on increasing the number of judges and administrative staff of arbitrazh courts in the Russian Federation introduced by the Highest Arbitrazh Court in (2001); Federal Law on total number of justices of the peace and judicial districts in the subjects of the Russian Federation (2001); Arbitration Procedure Code, introduced by the Highest Arbitrazh Court (2002); Federal Constitution Law on amendments to the Federal Constitution Law on the Constitutional Court of the Russian Federation (2001); Civil Procedure Code (2002); Amendments to the Law 
respect, clearly, Putin promoted judicial reform as part of his endeavour to harden the basic structure of the state. In fact, Putin's judicial reforms were originally meant to solidify the state's control of society, promoting a model of statehood based in a dictatorship of law (in Russian, диктатура закона): ${ }^{21}$ he expressly declared in his open letter to the Russian voters that a state not consistently governed by law is a weak state (Putin 2000). Notably, state building through legal/judicial reform is not unusual in Russian history; Russian leaders have a long history of reaching for the law, and of attempting to heighten its consistency, in moments of constitutional or structural crisis. ${ }^{22}$ Indeed, legal reforms promoted by Putin and Medvedev have been profoundly shaped by the sense that Russian society has a weak legal culture, or a long-standing tradition of legal nihilism, and that this adversely affects state integrity and government performance (Medvedev 2008). ${ }^{23}$ One motive behind Putin's judicial reforms, accordingly, was to restrict private monopoly of judicial office, to impose regularity on procedures for the enforcement of legislation across society, and, in so doing, to augment the vertical authority of the state executive. He made this point quite clear when he announced his plans for judicial reform in 2001; he claimed that lack of trust in the state had led to the proliferation of 'shadow justice', which meant that citizens were inclined to seek remedies for legal problems by private means, thus diluting the power of the central state. ${ }^{24}$ One further motive behind Putin's judicial reforms was that they were

of the Russian Federation 'On the Status of Judges in the Russian Federation' (2001); Amendments to the Federal Constitutional Law 'On the Judicial System of the Russian Federation' (2001).

21 There is an important distinction to be made with regard to this concept. 'Law' can be translated into Russian as both zakon and pravo. The former term is used to refer to a legislative act adopted by the Duma, while the latter corresponds to the more classical understanding of law as a system of rules. In his statement Putin used the term zakon, which slightly narrows down the meaning of the phrase 'dictatorship of law' to mean a society governed by unquestionable respect for and compliance with the acts of parliament. See Henderson (2011: 5-7).

22 Gorbachev's reforms in the 1980s were also focused, initially, on legal and judicial reform, designed to reinforce the independence of the courts. See Quigley (1990: 64); White (1990: 37); Kahn (2002: 87); Solomon (2004: 575). For earlier examples see Rudden (1994: 56); Wortman (2010: 9).

23 On the historical origins of these policies see Burbank (2006: 423-4).

24 Annual Address of the President of the Russian Federation to the Federal Assembly, delivered on 3 April 2001. As background to Putin's policies, see the account of shadow justice in Baranov (2002: 13-20). By 2012, Putin claimed that great success had been achieved in ending shadow justice. See Speech of the President of the Russian Federation at the viII National Congress of Judges, 18 December 2012. 
intended to alter the balance of Russian federalism, and to redress the centrifugalism encouraged by Yeltsin; Putin promoted judicial restructuring as a strategy for tying the regions more closely to Moscow and for creating a unified legal space across the whole of the Russian Federation. ${ }^{25}$ In each respect, Putin used legal and judicial reforms to enhance legal/political centralization, both vis-à-vis monetary/economic power and regional political monopolies. ${ }^{26} \mathrm{His}$ attempt to intensify the rule of law was clearly conceived as a means to raise the immediate authority of state power across society and to eradicate embedded knots of informal authority.

At a different level, however, it is observable that, from early in his period of influence, Putin viewed the problem of state debility, not only as a structural challenge to central institutions, but also as a normative constitutional problem, caused by the incomplete enforcement and societal recognition of constitutional norms. In consequence, his reformist responses to the threat of state collapse were not only designed to strengthen the abstract authority of the federal executive; they were also intended to extend the social penetration of constitutional law, and to heighten the standing of the Constitution as a source of publicly binding norms across society. In his early decrees promoting judicial reform, tellingly, Putin placed very particular weight on the link between judicial regularization and the realization of the Constitution, and he expressly stated that judicial reform was required to give full effect to constitutional norms (including basic constitutional rights). Judicial reform and constitutional enforcement were perceived as equally essential for the stabilization and reinforcement of the state. Indeed, the 'inviolability of the constitutional order' and the robustness of the state often appeared as synonymous in policy statements. ${ }^{27}$ This doctrine was eventually formulated by Medvedev (2013: 32-40), who stated: 'The Russian Constitution defines the objectives of public administration [...]. These include protecting the rights and freedoms of man and citizen, ensuring the sovereignty of the state, economic prosperity, integrity and security of the country, social justice, and others.'

On one hand, Putin promoted the generalized objective enforcement of essential constitutional provisions - including basic rights - as a crucial part

25 One of Putin's most important early orders was Decree No. 1486 of 10 August 2000: 'On Additional Measures to Ensure the Unity of the Legal Space in the Russian Federation'. See Sharlet (2001: 203); Kahn (2002: 234-38).

26 Kahn, Hanson and Teague (2005: 657); Yakovlev (2006: 1033); Easter (2008: 203); Sakwa (2008: 187); Trochev and Balayan (2009: 330).

27 Government of the Russian Federation Decree No. 1406 of 27 December 2012 'On the Federal Target Program “Development of the Russian Judicial System in 2013-2020'. 
of his plan to counteract the privatization of public order which had escalated through the 199os. Accordingly, he justified his legal/judicial reforms by claiming that 'the development and strengthening of the judiciary as an independent branch of government' was required to give full effect to the Constitution, including 'the rights and freedoms' that it enshrined. ${ }^{28}$ Tellingly, Valery Zorkin (2004), the first and current Chairman of the Russian Constitutional Court (RCC), argued that, for the first ten years after the 1993 Constitution came into force, 'the biggest and the most real threat to the country was a collapse of the state', and he identified strict application of constitutional law in the superior courts as a precondition for prevention of state fragmentation. For both Putin and Zorkin, the more consistent implementation the constitution (including basic rights) and the solidification of the state appeared as inseparable parts of the same process.

On the other hand, Putin also construed more consistent enforcement of the constitution as a technique for resolving imbalances in the federal system. Notably, one striking consequence of Yeltsin's treaty-based negotiation with regional rulers was that many regional treaties and laws deviated from the provisions of the Constitution, ${ }^{29}$ often according powers to non-federal bodies that clearly exceeded relevant constitutional provisions (Ross 2009: 19). ${ }^{30}$ In fact, regional governments that had assumed high levels of independence in the 1990s were typically amongst the most authoritarian actors in the Federation, and they were widely guilty of violating both the Russian constitution and general human rights norms (Shlapentokh, Levita and Loiberg 1997: 214; Moraski 2006:10; Ross 2009: 19). The stricter enforcement of constitutional law, linked to extensive judicial reform, was thus promoted as part of Putin's

28 Government of the Russian Federation Decree No. 805 of 20 January 2001 'On the Federal Target Program 'Development of the Russian Judicial System in 2002-2006'.

29 The General Procurator calculated that $34 \%$ of regional laws openly contradicted the constitution. See Hyde, (2001: 731). The official statistic is even higher: of 41 RCC rulings on the constitutionality of regional laws and constitutions the unconstitutionality verdict appears in 32 rulings (78\%), most of them in late 1990s and early 2000 ( $\mathrm{http}: / / \mathrm{www}$ .ksrf.ru).

30 Many sovereign powers acquired by the republics and other subjects were in derogation of the 1993 constitution, especially Arts 77(2), 8o(2), 85(2) and 90. For example, in 2001 the Supreme Court ruled considered a case for constitutionality of a provision of the Constitution of Komi Republic that stated that 'the State Council of the Komi Republic decides on the state structure of the Republic of Komi.' The Supreme Court ruled that: 'Questions of determination of the federal structure and the territory of the Russian Federation lie within the exclusive jurisdiction of the Russian Federation': Supreme Court Ruling No. 3-Go1-10 of 13 April 2001. 
wider strategy to establish a unified legal space across the entire federation, with the national Constitution and its provisions for basic rights as the focal point of legal order. Indeed, Putin first announced his legal/judicial reforms by explaining that many powers granted to federal subjects had come to breach the Constitution, and by declaring his intention to combat some regional legislation on grounds of unconstitutionality (Kahn 2002: 245). ${ }^{31}$ This strategy was strongly backed by the RCC, which in leading rulings agreed (quite correctly) that some republics had arrogated powers without constitutional authority. ${ }^{32}$

In sum, the earlier part of Putin's period of influence was defined by the overriding problem of stateness and its absence, and he devised different methods to revive (or perhaps to create ex nihilo) a basic structure for the Russian political system. One of these methods was primarily, although not exclusively, oriented towards a vertical reinforcement of the central executive. Another method, however, was primarily, although not exclusively, orientated towards an extension of the societal reach of constitutional law, placing hard emphasis on the Constitution and constitutional rights as the demonstrably public fulcrum of society's legal/political order. Since 2000, leading actors in the political system have repeatedly sought to mobilize the Constitution for state-building purposes, and judicial reform, giving objective reality to the Constitution, has been identified as a primary means to correct the underlying structural weakness of the state. To be sure, many important researchers cast doubt on the efficacy of Putin's state-building initiatives (Taylor 2011: $3,26,162) \cdot{ }^{33}$ At least in intention, however, successive governments have placed increased constitutional enforcement and legal/judicial reform at the centre of a consistent program of political capacity building.

\section{Legal Autonomy and Secondary Constitutionalization}

It is in this context that we can begin to outline a sociological approach to the foundations of the Russian Constitution, and to the social practices which shape its evolution. Indeed, the general fact that heightened implementation

31 "New Objectives for the President's Representatives in the Regions", 26 December 2000, Nezavisimaya gazeta. [Online] Available from: http://www.ng.ru/politics/2000-12-26/3 _new_task.html [Accessed 29 September 2016].

32 See RCC Ruling on Admissibility No. 92-O of 27 June 2000; RCC Ruling on Merits No. 10-P of 7 June 2000 .

33 The more standard view is that Putin, to some degree, has enhanced the capacities of the state (Easter 2008: 199). 
of the Constitution has been pursued as a means for rectifying underling systemic weaknesses in governance structure has clear legal-sociological implications. On one hand, this means that governance institutions rely on the constitution to cement their position in society. In turn, this means that judicial institutions acquire particular importance as bodies that interpret and enact the Constitution, and that map the Constitution on to given societal circumstances. Then, the reliance of the political system on judicial institutions to strengthen the constitution means that judicial practices assume a distinct autonomy. Autonomy is used here in two distinct but related ways: it implies, first, that actors and exchanges in judicial institutions have, with limitations, become more independent; it implies, second, that these exchanges have acquired a particular ius-generative quality, as interactions that promote the secondary construction of constitutional norms. These claims need to be made with certain clear and emphatic caveats. However, in certain respects, the judicial system now forms a distinct and relatively independent domain of constitutionally formative social practice. ${ }^{34}$

Quite manifestly, there is much literature on Russian law that casts doubt on the independence and the efficacy of current judicial institutions. This view is expressed for different reasons. For example, some observers denigrate the performance of legal institutions by stressing the scale of judicial corruption; others focus on the political role of courts and suggest recurrent political collusion amongst judges (Ledeneva 2008: 328, 330; Hendley 2009: 242). Alternatively, as mentioned, some researchers suggest that judicial independence merely exists at a symbolic level, and that courts refuse to enforce the law in questions of high politics (Thorson 2012: 152; Mazmanyan 2015: 214). ${ }^{35}$ Some critics indicate that the position of the Procuracy means that political control of judicial functions is exacerbated (Fish 2005: 45; Burger and Holland 2008: 142-193). Finally, some analysts refer to opinion polls to prove that the judiciary is among the least trusted branches of the government. ${ }^{36}$

34 See pp. 770-74 below.

35 This view is less strongly endorsed in research conducted at the highest level (Trochev 2008: 185).

36 As a most notable example, Ledeneva (2008: 341) claims, admittedly in an older article, that the conviction that judges are susceptible to bribery is widespread, with over $54 \%$ of the population claiming that judges can be bought. In this respect, however, it is clear that opinion polls do not constitute the most reliable source of information about the level of trust in the independent courts in Russia. Indeed, people who criticize the Russian judicial system as 'totally corrupt' base their judgment on the results of published opinion polls, consistently reporting that the level of public trust in the judiciary is very low. Moreover, the level of information the respondents receive about courts is 
As will be discussed, however, the status of the legal system as an autonomous normative domain, although not securely guaranteed, is quite embedded in the Russian political order as a whole. ${ }^{37}$ This does not mean that there is no informal control of legal functions. But the autonomy of judicial practices, in the twofold sense, is evident in a range of different ways. The growing autonomy of the Russian legal system is reflected, most visibly, in a series of judicial reforms pursued in Russia since the 1980s, which have repeatedly defined legal autonomy as a very high-priority policy objective. Before 1993, laws had already been passed to enhance judicial independence. ${ }^{38}$ Arts 120-24 of the 1993 Constitution expressly protected the independence of judges. Art 125, establishing a Constitutional Court, was clearly intended to preserve the legal system from direct intervention by the political executive. Measures to enforce constitutional provisions for judicial autonomy were then strengthened in $1996{ }^{39}$ Since 1999, however, there have been more specific attempts

very low, the main sources of information being TV shows, anecdotes, and even 'gossip in markets and shops' (See wсіом 2007: 8). In 2005 the Russian Public Opinion Research Center (WсIOM) conducted independent research on trust in the judiciary. It shows that among those respondents who had experience of applying to courts, $19 \%$ of respondents assessed the work of the courts in very positive terms, whereas among those who did not have such personal experience only $5 \%$ gave a favourable assessment of the judiciary. The same methodology in 2013 yielded a similar result. Only $18 \%$ expressed trust in courts, but the number of respondents who admitted that they personally have not encountered corruption during that year increased from $46 \%$ to $80 \%$ (See wсгом 2005). Consequently, it is clear that lack of official and trustworthy information about courts perpetuates a negative stereotype. Notably, in 2008, Ledeneva claimed (2008: 341) that persons who had had first-hand experience of the judiciary had a more sceptical view of judges that those who had none. However, this very negative assessment is not borne out by subsequent developments. Our claims are very strongly supported by recent data compiled by Hendley (2015:2), who argues that a large proportion (over 70\%) of persons with first-hand experience of judicial process are likely to evaluate the judgements handed down by courts as mostly or entirely fair.

37 This is a minority view. But it is supported, in part, by other researchers (see Hendley 2011: 257; Trochev 2012: 19; Hendley 2013: 557). Some of the research asserting the contrary relies on rather out-dated and anecdotal evidence. See poor use of sources and inaccurate compilation of statistics in Mazmanyan (2015: 203, 205). Mazmanyan argues that the RCC has no power to initiate legislation, although Art 104 of the Constitution clearly provides for the contrary. Notably, the Supreme Court has sought to initiate legislation on 120 occasions, with a $40 \%$ success rate.

38 Federal Law of 26 June 1992 No. 3132-I 'On the Status of Judges in the Russian Federation'.

39 Federal Constitutional Law of $3^{1}$ December 1996 No. 1-FKZ 'On the Judicial System of the Russian Federation'. Art 5(1) of this law states: 'The courts exercise judicial power 
to guarantee and augment the independence of Russian judicial institutions. For instance, Art 8 of the Civil Procedure Code introduced by the Supreme Court in 2000 and adopted in 2002 is designed to elevate judicial autonomy. In recent legislation, this emphasis has become still more marked. In 2013, a new federal law was adopted that hardened guarantees for the independence of judges by explicitly prohibiting extra-procedural communication with judges. ${ }^{40}$ The recent Administrative Litigation Code of the Russian Federation (2015) also contains a separate article on judicial independence. Throughout this period, moreover, salaries for judges have increased rapidly, so that judges are now amongst the most highly paid public officials. This is clearly intended to raise the prestige of the judiciary, to attract high-quality professionals, and to reduce judicial corruption. ${ }^{41}$ Through this period, further, courts have responded to government initiatives by developing principles of jurisprudence, which emphasize their independence and which underline the autonomy of the legal system as a functional domain. This is strikingly visible in the fact, as discussed more fully below, that courts have taken increasing pains to link their rulings to international law, and to found their arguments on principles which, owing to their international provenance, are not easily susceptible to political control. ${ }^{42}$ In 2003, for example, at the end of the first decade of its operations, the Supreme Court issued the Plenum Ruling No. 5 'On Application by the Courts of General Jurisdiction of the Universally Recognized Principles and Norms of International Law and International Treaties of the Russian Federation', which was intended to encourage the use of international law in all courts. More importantly, the courts received a clear and direct instruction to apply rulings of the European Court of Human Rights (ECtHR) containing interpretation of the norms of the European Convention on Human Rights (ECHR) relevant to the case under their consideration. ${ }^{43}$ In each respect, the insistence on the essential autonomy of law has formed a constant, and increasingly accentuated, component of the push for systemic reform and state reinforcement in Russia.

independently, regardless of someone else's will, subject only to the Russian Constitution and the law.'

Federal Law No. 166-FKZ of 2 July 2013 'On Amending Certain Legislative Acts of the Russian Federation'. The same law has introduced a dedicated article on independence of judges into the Criminal Procedure Code, an unprecedented measure aimed at guaranteeing more procedural autonomy of the judges in criminal proceedings. The first salary increase was signed into force by Putin on 24 November 2000.

This has only recently become general practice. But it is based in earlier legislation, notably Article 3 of the Federal Constitutional Law No. 1-FKZ of 31 December 1996 'On the Judicial System of the Russian Federation'. 
Most importantly, however, the normative autonomy of the legal system becomes perceptible, not if we listen to what people say about legal institutions, but if we observe what they do in the legal domain, and if we study the outcomes of their engagement in legal procedures. Seen from this perspective, the rising autonomy of the judicial system is apparent in the proliferation of legal action, and especially in the expansion of litigation. ${ }^{44}$ In addition, the rising autonomy of the judiciary is evident in the fact that legal actions, and especially litigation, measurably shape the public order of government. Legal practices in fact have a directly constitutive effect for the political system in Russia, and they act, in some respects, as a relatively autonomous source of constitutional norms. Accordingly, the sociological core of the Russian constitution might be seen to lie in the fact that, owing to the socio-historical pressures discussed above, political actors have promoted the stabilization of the political system through consolidation of the Constitution, largely effected by judicial reform. ${ }^{45}$ As a result of this, the Constitution forms a distinct nexus between the political system and society more widely, and judicial bodies have assumed a certain functional independence in interacting with social agents and in constructing the material form of the Constitution. In fact, the sphere of judicial activity forms a domain of norm construction which is not fully subject to strategic control, and it acts as a channel for distinct modes of constitutional practice, ranging from macro-sociological patterns of institutional consolidation, to micro-sociological acts of litigation and judicial interpretation, all of which imprint distinct secondary norms on the constitutional order. Overall, the crisis of statehood in the 199os produced an adaptive pathway, in which judicial reinforcement of the Constitution became a precondition of state stability, and the Constitution was progressively reconfigured by societal communications especially linked to acts of litigation - mediated through the courts.

This autonomous constitutionalizing impact of legal practices is exemplified in the following processes:

\subsection{Secondary Constitutionalization 1: International Law}

One distinctive constitutional feature of the Russian polity has become visible, first, in the high importance that is accorded to international law. Importantly, judicial bodies play a key role in developing this aspect of the constitutional order, and litigation plays a crucial role in heightening the standing of international law in domestic law.

44 See below p. 774-80.

45 On the nexus between constitutional implementation and state-building see Sharlet (1999: 98). 
The impetus towards constitutional recognition of international law was already evident in early constitutional reforms, beginning in the 1980 s. For example, in 1990, the Declaration of State Sovereignty of the Russian Soviet Federal Socialist Republic (RSFSR) announced that the reformed state had a strong 'commitment to the universally recognized principles of international law'. ${ }^{6}$ The same principle was reflected in the 1991 USSR Declaration of Human Rights and Freedoms, ${ }^{47}$ which proclaimed international covenants a basis for domestic human rights. In turn, the RSFSR Declaration of the Rights of Man and Citizen established the primacy of 'international law, particularly human rights norms' above RSFSR legislation. ${ }^{48}$ The year 1991 also saw the adoption of the Concept of Judicial Reform, ${ }^{49}$ which identified international law as an important source of law, regardless of whether it had been formally incorporated in the domestic legal system. This Concept stipulated that the 'universally recognized principles' of international law (interpreted at that time as jus cogens) should have higher authority than domestic legislation. ${ }^{50}$

These provisions were later transposed into the text of the Russian Constitution of 1993. Formally, the 1993 Constitution is very monistic, and universally recognized principles and norms of international law and international treaties of the Russian Federation are considered a component part of the Russian legal system (Art 15(4)). Accordingly, international norms have direct effect in domestic law, and, when cited by courts, they have an important place in the established hierarchy of legal norms. International treaties of the Russian Federation, in particular, have unquestionable priority over conflicting norms of domestic legislation, and they obtain direct legal force immediately following their ratification by a federal law and official publication, unless the relevant treaty expressly provides otherwise. ${ }^{51}$ Legislation regulating both substantive and procedural matters contains so called 'priority of international law' clauses, which, referring to Art 15(4) of the Constitution, provide for the invalidation of legislative norms in cases of conflict with any international treaty of the Russian Federation.

\footnotetext{
46 Declaration of State Sovereignty of the RSFSR of 12 June 1990.

47 Declaration of Human Rights and Freedoms of the Union of Soviet Socialist Republics (USSR) No. 2393-I of 5 September 1991.

48 Declaration of the Rights of Man and Citizen of the RSFSR adopted by the RSFSR Supreme Soviet's Resolution No. 1920-1 of 22 November 1991.

49 Supreme Soviet of RSFSR Decision No. 1801-1 of 24 October 1991 'On the Concept of Judicial Reform in RSFSR'.

$50 \quad$ Ibid.

$5^{1}$ Article 5(3) of the Federal Law No. 101-FZ of 15 July 1995 'On International Treaties of the Russian Federation'.
} 
To be sure, there remain certain limits to the immediate enforcement of international law in Russia. For instance, the Constitution enumerates three separate types of international regulations, and these are accorded rather varying status in the legal system. These types are: 1) principles; 2) norms of international law; 3) international treaties. Notably, priority over national law is only accorded to the latter type (treaties). Moreover, international treaties do not have higher authority than the Constitution itself, and the RCC has interpreted Article 15(1) of the Constitution to guarantee absolute supremacy of the constitution over international law. Most recently, in a seminal ruling on the legal status of constitutional norms vis-à-vis conflicting rulings of international courts, ${ }^{52}$ the RCC interpreted Art 15(1) as allowing Russia to refuse to implement those decisions of ECtHR that are at variance with the Russian Constitution. ${ }^{53}$ Despite these limitations, however, the standing of international law in the Russian Constitution remains unusually high. Generally, the supremacy of the Constitution is construed, not as a principle for invalidating international law, but for ensuring the 'harmonious interaction of national and international decisions in the Russian legal system' (Zorkin 2011a).

What is especially notable in these processes is that, since 2000, the original provisions in the Constitution for the incorporation of international law in Russia have been much more frequently enforced. Prior to 2000, there had been virtually no cases in which a court had referred to provisions in the Constitution or in a federal law safeguarding the priority of international law to give direct effect to a provision of an international treaty in a case where a federal law was in conflict with it. ${ }^{54}$ Since 1999, however, the initially weak objective penetration of international law in the Russian legal system has been markedly intensified.

On one hand, the standing of international law has been deliberately reinforced through Putin's legal/judicial and political reforms, and it is clearly linked to his plans for structural reinforcement of the state. In the first two years of his Presidency, Putin introduced large swathes of legislation to stabilize some of the more precariously regulated areas of Russian society. At this time, almost 400 federal laws were introduced by the President and adopted by the Duma as urgent measures to address vital questions such as privatization, employment,

$5^{2} \quad$ RCC Ruling on Merits No. 21-P of 14 July 2015.

53 This principle was later reinforced by respective amendments to the Federal Constitutional Law 'On the Constitutional Court of the Russian Federation', see Federal Constitutional Law of 14 December 2015 No. 7-FKZ. For comment see Antonov (2014: 1-40).

54 For one early example see Higher Arbitrazh Court Presidium Ruling No. $7863 / 98$ of 3 August 1999 . 
land use and ownership, state registration of businesses, money laundering, political parties, and pensions. Notably, these laws were firmly underscored by principles of international law through 'priority of international law' clauses. International law was expressly assimilated at this time because it was seen as a valuable instrument for establishing legal uniformity across society, for consolidating the 'unity of legal space' across the Russian Federation, ${ }^{55}$ and for promoting reliable constitutional principles to support new legislation, especially in legally unstable areas of social practice. At roughly the same time, Putin also gave effect to measures to formalize principles of accountability for public authorities in the subjects of the Russian Federation, ${ }^{56}$ and to establish conditions for local self-government, ${ }^{57}$ which were underpinned by international norms. In 2001-2002, additionally, all of the major procedural codes were renewed in accordance with the new Constitution and Russia's international obligations. ${ }^{58}$ In each of these respects, use of international law was clearly intended to heighten the consistency of the domestic legal order, and to solidify the legal foundations of the state across society (Tiunov 2011: 85).

On the other hand, the assimilation of international law in Russia has also occurred through less strategic processes, and it has had less consciously deliberated consequences. In particular, acts of litigation have assumed important constitutional resonance in this regard, and litigation often leads to a consolidation of the position of international norms in domestic constitutional law. In recent years, notably, some primary concepts of international law, particularly principles derived from ECtHR jurisprudence, have been widely appropriated in Russian case law, and they have even gained pervasive influence in legislative acts. ${ }^{59}$ In this respect, international law has clearly intensified the constraints within which government bodies are expected to act, and it has helped to flesh out a more robust body of public law, in which individual agents can more easily appeal to formal norms against public bodies.

55 Presidential Decree No. 1486 of 10 August 2000: 'On Additional Measures to Ensure the Unity of the Legal Space in the Russian Federation'.

$5^{6}$ Federal Law No. 184-FZ of 6 October 1999 'On General Principles of Organization of Legislative (Representative) and Executive Bodies of Subjects of the Russian Federation'.

57 Federal Law No. 131-FZ of 6 October 2003 'On General Principles of Local Self-Government in the Russian Federation'.

$5^{8}$ Criminal Procedure Code of the Russian Federation No. 174-FZ of 18 December 2001; Code of the Russian Federation on Administrative Offenses No. 195-FZ of 30 December 2001; Arbitration Procedure Code No. 95-FZ of 24 July 2002; Civil Procedure Code of the Russian Federation No. 138-FZ of 14 November 2002.

For a very extensive research on the topic see Burkov (2010). 
Since Russia's accession to the ECHR in 1998, for instance, the ECHR has acquired a very important position in Russian public law, and citations from the Strasbourg court are increasingly common. In the last nine years, the RCC cited ECHR in more than ninety rulings, ${ }^{60}$ and currently more than $40 \%$ of the RCC's rulings on merits (Postanovleniya) refer to the ECHR. ${ }^{61}$ Between 2000 and 2014, the highest Russian courts - that is the Supreme Court, the RCC, and the Higher Arbitrazh Court - cited the ECHR well over 2,00o times, with an accelerated level of citation after 2006. ${ }^{62}$ By 2013, annual citation of the ECHR by regional courts reached over 6,00o cases. In the period 2012-2014, the number of rulings of regional courts referring to ECHR almost doubled (from 3,80o to 7,400 ). Not without justification, the Strasbourg court has been called 'the most popular court in Russia' (Trochev 2009: 145). As a result, it is now widely noted that consistent application of ECtHR rulings has a deep influence on judicial practice through the Russian Federation, even in remote regions. Indeed, one reason why judicial citation of ECtHR rulings is widespread is because this allows lower courts to ensure that their rulings are consistent with national practice, and it protects lower courts from censure by superior courts. ECtHR rulings are thus extensively used as standard templates for domestic judicial rulings. ${ }^{63}$ Very importantly, moreover, Russian courts increasingly refer to ECtHR judgments concerning Russia itself: of 3,573 judgments against Russia 1,450 have been cited by Russian courts, in 23,957 rulings. In the higher courts, the RCC referred to 330 ECtHR judgments, including 149 against Russia, while the Supreme Court has referred to 754 ECtHR judgments, including 172 against Russia. Most importantly of all, however, much citation of international law has occurred in cases against government bodies.

6o Internet interview with Valeriy Zorkin, Chairman of the Constitutional Court of the Russian Federation: 'Preliminary Results of the Constitutional Court of the Russian Federation on the Threshold of the 15th Anniversary', Consultant.ru, 6 April 2006. [Online] Available at: https://www.consultant.ru/law/interview/zorkin/ [Accessed 29 September 2016].

61 As reflected in the legal database 'ConsultantPlus' [Online] Available at: www.consul tant.ru [Accessed 29 September 2016]. The source of statistical data used in this article, unless otherwise noted, is the official court statistics published on the website of Judicial Department of the Russian Supreme Court (2002-2015). This is available at: www.cdep.ru/ index.php?id=79 [Accessed 29 September 2016].

62 It has been argued that citations from the ECtHR are usually marginal to the core claims of legal cases (Antonov 2014). However, this is not unusual for national courts in Europe, and it does not of itself undermine the normative authority of the ECHR.

63 See the report by the Chairman of Belgorod Oblast Regional Court, Justice Ivan Zazdravnykh (2010). 
Between 1998 and 2014, there were at least 200,000 anti-government cases that cited the ECHR.

In addition to regular citations from ECtHR jurisprudence in common courts, individual and general measures prescribed by the Strasbourg court are also adopted on a regular basis. To be sure, Russia remains one of the ten countries that have the highest number of non-implemented ECtHR judgments, and it clearly still faces 'serious structural problems' in this regard; ${ }^{64}$ around 1,400 judgments against Russia remain unimplemented. ${ }^{65}$ Despite this, however, there is no principled disagreement between Moscow and Strasbourg regarding the majority of ECtHR judgments. In fact, Russia makes a substantial legislative and organizational effort to implement ECtHR judgments both with regard to compensation and general measures. Annual federal budget legislation contains a clause on compensation in accordance with ECtHR judgments. The size of the compensation budget has increased from 114 million rubles ( 1.7 million USD) in 2010 (see Vorontsova and Solovieva 2010: 88 ) to 500 million Rubles (7.6 million USD) in $2016 .{ }^{66}$ Since 2011 , further, the Russian government has monitored the implementation of ECtHR judgments. In the most recent report the government provides data on legislative change following the respective ECtHR judgments. ${ }^{67}$ The most important recent examples of general measures include legislation adopted to eliminate systemic violations regarding excessive delays in legal investigations and judicial proceedings ${ }^{68}$ forcible detention in psychiatric institutions, ${ }^{69}$ communications between a prisoner or a detained person and his/her representative in

64 Parliamentary Assembly of the Council of Europe Resolution No. 2075 (2015) of 30 September 2015 'Implementation of Judgments of the European Court of Human Rights'.

65 'Russia has provided for only $0.4 \%$ compensation in the Yukos case in 2016 budget' [Online], RBC, 9 October 2015. Available from: http://www.echr.ru/news/msg.asp?id_ msg $=3670$ [Accessed 29 September 2016].

66 Federal Law No. 359-FZ of 14 December 2015 'On the Federal Budget for 2016'. Art. 21(5).

67 Report on the Results of Monitoring of Law Enforcement in the Russian Federation in 2014. [Online] 14 December 2015. Available from: http://government.ru [Accessed 29 September 2016]: Annex 4.

68 Federal Law No. 68-FZ of 30 April 2010 'On Compensation for Violation of the Right to Justice in Reasonable Time or the Right to Execution of the Judgment in Reasonable Time', adopted to implement the pilot ruling Burdov v. Russia (No. 2) (Application no. 33509/04, Judgment of 15 January 2009).

69 Federal Law No. 302-FZ of 30 December 2012 'On Amendments to Chapters 1, 2, 3 and 4 of the Civil Code of the Russian Federation', adopted to implement Shtukaturovv. Russia (Application No. 44009/05, Judgment of 27 March 2008). 
the ECtHR, ${ }^{70}$ physical abuse in military bases, ${ }^{71}$ pre-trial detention conditions, ${ }^{72}$ deportation, ${ }^{73}$ cancellation of adoption ${ }^{74}$ and other areas.

In each of these respects, a distinctive process of secondary constitutionalization has become visible in Russia, in which interactions in legal institutions shape the constitutional form of the political system. At one level, international law is used, by specific executive design, to increase the unity of the political system. At a different level, however, international law also enters the legal order in less easily controllable fashion. In each respect considered above, actors and actions in the legal system have clearly assumed a partly constituent authority. Above all, acts of litigation lead to the internalization of international norms in the domestic constitution, which have established and promoted patterns of secondary constitutionalization, autonomously hardening the constitutional norms that regulate government agencies. As a result, the Russian political system as a whole has clearly evolved towards a design in which the obligations of public bodies are more strictly determined, and relatively hard legal norms, backed by the authority of international courts and conventions, are used, not only to intensify the reach of the state, but to produce a framework for the legitimate exercise of public power. No claim is made here that this creates a comprehensive constitutional order. In the processes outlined above, however, the autonomous dynamic of secondary constitutionalization has created a constitutional system which clearly places increased emphasis on legal accountability.

\subsection{Secondary Constitutionalization 2:Judicial Control and Political Questions}

Relatively autonomous patterns of secondary constitutionalization are also visible in the functions which judicial institutions have assumed vis-à-vis other branches of government. Of course the role of the judiciary in this domain is badly tarnished. It is widely accepted, for example, that courts have curtailed powers in their exchanges with the core executive, and in recent

\footnotetext{
70 Federal Law No. 193-FZ of 28 June 2014 following Zakharkin v. Russia (Application No. 1555/04, Judgment of 10 June 2010).

71 Presidential Decree No. 161 of 25 March 2015, amending the Presidential Decree No. 1495 of 10 November 2007, following Putintseva v. Russia (Application No. 33498/04, Judgment of 10 May 2012).

72 For Ananyev, Kalashnikov and further changes to pre-trial measures see: 'Russia Reported on Non-Execution of Strasbourg Judgments' [Online]. RBC, 14 April 2015. Available from: http://www.echr.ru/news/msg.asp?id_msg=3474 [Accessed 29 September 2016].

73 Ibid., re. Garabayev.

74 Ibid., re. Ageev \& Ageeva.
} 
high-profile cases with political implications judicial procedures were influenced by political factors (Sakwa 2011: 44). Examples of such cases are the cases of Khodorkovskiy (YUKOS), Vassilieva (Oboronservis), the Ukrainian pilot Savchenko, and a series of trials connected with the Khimki Forest and Bolotnaya Square protests. As discussed below, however, reforms since 2000 to the judiciary have induced a rapid general rise in the quantity of cases brought before the Russian courts. ${ }^{75}$ Notably, these reforms also led, initially, to a striking increase in litigation against government actions. The majority of claims challenging illegal actions or decisions of federal and regional bodies are aimed at resolving more commonplace administrative complaints. However, there is also evidence to suggest that the courts are consistently willing to intervene in questions located in the domain of the executive to impose stricter constitutional constraints on actors in the federal government, and even to initiate legislation against the preferences of the executive.

The willingness of judicial actors to check other government branches is usually most manifest in policy questions. For example, there are notable cases in which Russian courts have taken action to challenge federal immigration policy, especially concerning deportation of aliens. In particular, the courts have done this by insisting that immigration policies must show regard for the family ties, the health condition, and the risks to the life of persons subject to deportation by public officials. As a result of such judicial interventions, deportation orders have been quashed for persons with immediate family members, especially dependents, in Russia. ${ }^{76}$ Similarly, deportation orders have been annulled for HIV-infected persons at risk of being denied equal medical treatment in the country to which they are threatened with forcible return. ${ }^{77}$ Deportation orders have also been declared void for other humanitarian reasons. ${ }^{78}$ The Supreme Court summarized judicial practice in this regard in its 2013 guidelines, advising lower courts to take Article 8 ECHR into consideration in all cases concerning administrative deportation of foreign citizens. ${ }^{79}$ This intervention by the Supreme Court effectively changed the way in which

\footnotetext{
75 See below pp. $774-80$.

76 See, among a number of other decisions, Supreme Court Decision No. 18-AD14-58 of 7 November 2014; Abinskiy District Court of Krasnodarsky Krai Decision No. 5-116/14 of 11 April 2014.

77 RCC Ruling on Merits No. 4-P of 12 March 2015; RCC Ruling on Admissibility No. 155-O of 12 May 2006.

78 Moscow Oblast Regional Court Decision No. 1888/14.

79 Supreme Court Plenum Ruling No. 5 of 24 March 2005 'On some issues arising from application of the Code on Administrative Offenses by courts' (amended on 19 December 2013): Para. 23.1.
} 
deportation cases are considered by courts throughout the country, although the current federal legislation makes no provision for additional protection of guarantees for persons facing deportation. ${ }^{80}$ In addition, there are prominent cases in which courts have overruled policies concerning social development programs adopted by regional governments. Indeed, regional development programs are often struck down by the Supreme Court as violating federal legislation, usually on the grounds that they fall short of minimal social protection requirements prescribed under federal regulations. Significantly, such rulings have affected regional programs concerning agriculture, free medical aid, affordable housing, and development of rural regions, entrepreneurship, tourism, social aid and such. ${ }^{81}$

Very striking in this regard is the fact that the RCC has also struck down parts of the yearly Federal State Budget on grounds of unconstitutionality, finding that the budgetary plans breached legitimate expectations in cases where they failed to recognize specific social rights obligations. In such cases, lack of public funds was not seen as a justification for state actions in derogation of commitments to provide for social rights, and the courts have refused to see allocation of public funding and resources as a fenced-off policy area. ${ }^{82}$ Furthermore, there are numerous cases in which the RCC has intervened in questions regarding taxation policy, a core traditional domain of exclusive governmental competence. In the period 2007-2014, the Court invalidated several provisions of the federal Tax Code. ${ }^{83}$ As a result of some of these cases, important aspects of taxation policy were amended. These changes entailed the

8o A draft federal law No. 709323-6 was introduced in 2015 to provide for more flexibility for judges in imposing deportation as an administrative punishment, and to exclude the unconditional nature of this sanction with reference to Article $8 \mathrm{ECHR}$ and ECtHR jurisprudence. On 7 April 2015 the consideration of this draft was temporarily suspended. As of 29 September 2016 no further action has followed.

81 See, among more than a hundred, Supreme Court Ruling No. 74-APG14-6 of 13 August 2014; Supreme Court Ruling No. 1-APG14-17 of 26 November 2014; Supreme Court Ruling No. 48-G10-33 of 17 November 2010; Supreme Court Ruling No. 58-Gog-22 of o3 February 2010; Supreme Court Ruling No. 74-Go9-16 of 19 August 2009; Supreme Court Ruling No. 58-G07-10 of 18 July 2007.

82 See RCC Ruling No. 9-P of 23 April 2004. In many countries, of course, Justices view budgetary policies as a ring-fenced domain of executive competence. One example is the UK. See Nottinghamshire County Council $v$ Secretary of State for the Environment; and another appeal - [1986] 1 All ER 199 (Scarman L. J.).

83 Tax Code of the Russian Federation (Part One) No. 146-FZ of 31 July 1998; Tax Code of the Russian Federation (Part Two) No. 117-FZ of 5 August 2000. 
elimination of double taxation for individuals, ${ }^{84}$ protection of the right to file judicial review claims against the federal taxation authorities, ${ }^{85}$ and protection of the rights of businessmen against excessive inspection. ${ }^{86}$ Also important are the interventions of the RCC in cases regarding the sovereignty and territorial integrity of federal regions (Chechnya, Tatarstan) (see Zorkin 2011b).

Perhaps the most important example of judicial involvement in high politics, however, occurred when the RCC instituted a de facto abolition of the death penalty. This was achieved, first, through the Court's moratorium on executions in 1999. ${ }^{87}$ Ultimately, this was secured in $2009,{ }^{88}$ when the Court held that imposition of the death penalty is invariably unconstitutional, despite the lack of any legislative decision to exclude the death penalty from the Criminal Code (Zorkin 2009). Very notable in this respect is the fact that the rulings of the RCC requiring a revision of federal legislation are usually implemented quite effectively. The level of implementation is described by the RCC itself as 'steadily positive', despite a small backlog of 17 unimplemented rulings out of 72 of all rulings requiring alterations to existing laws. ${ }^{89} \mathrm{In} 2014$, in fact, the RCC invalidated 20 acts of federal legislation and recommended that the Duma adopt legislation on 16 unregulated issues. In the same year, 20 federal laws were adopted to give effect to the RCc's rulings.

Political intervention of the Supreme Court, further, is very strikingly visible in the fact that it conducted judicial review of several decrees that had been issued by a powerful organ of Putin's administration - the Standing Committee of Inquiry. For example, the Committee's directives setting out procedures for control of its own internal and external functions were invalidated by the Supreme Court. ${ }^{90}$ The reason given for this was that these directives failed to comply with the requirement that all acts of secondary legislation

84 RCC Rulings on merits No. 19-P of 1 July 2015; No. 33-P of 25 December 2012.

85 RCC Ruling on merits No. 6-P of 31 March 2015.

86 RCC Ruling on merits No. 5-P of 17 March 2009.

87 RCC Ruling on Merits No. 3-P of 2 February 1999. This occurred despite Yeltsin's failure to include a similar provision in his 1996 Decree: Presidential Decree No. 724 of 16 May 1996 'On Phasing out of the Death Penalty in Connection with Russia's Accession to the Council of Europe'.

88 RCC Ruling on Admissibility No. 1344-O-R of 19 November 2009.

89 RCC, 'Analytical Report on the Implementation of Decisions of the Constitutional Court of the Russian Federation, Adopted in the Course of Constitutional Proceedings in 2014', KSRF.RU, 15 April 2015.

9o Supreme Court Ruling No. AKPI14-100o of 15 October 2014; Supreme Court Ruling No. AKPI16-547 of 15 August 2016. 
affecting human rights must be registered by the Ministry of Justice. ${ }^{91}$ This rule is designed to ensure that all executive bodies regulate questions concerning human rights in consistent fashion.

In each of these instances, the highest Russian courts have acted as de facto legislators, or even as constitutional subjects, defining higher-order norms for new acts of legislation (primary and secondary). In each of these respects, more widely, judicial actors and actions can again be observed as assuming a secondary constitutionalizing impact on the Russian political system as a whole. Of course, judicial activism is widespread in most contemporary national polities, and many states are marked by rising judicial involvement in high-level politics; the tightening of legal accountability by courts is a globally widespread constitutional process (Hirschl 2000: 104; Baudenbacher 2003: 397; Teitel 2011: 216). ${ }^{92}$ Moreover, judicial control of legislation is foreseen in the literal text of the ${ }_{1993}$ Constitution, especially in Art 125. Nonetheless, in Russia, the essential constitutional architecture of government has been partly defined through relatively autonomous legal acts. In fact, whereas in other societies judicial activism is widely perceived as a process that by-passes embedded patterns of democracy and dislodges established constitutional norms (Ferejohn 2002: 41, 44; Hirschl 2007: 723), in Russia such activism forms a cycle of interaction between the political system and society. Sociologically, the legal system represents an environment of ongoing constitution making, in which litigation is a primary mode of constitutional practice.

\subsection{Secondary Constitutionalization 3: Rising Administrative Litigation}

Linked to these processes is the fact, as mentioned, that recent years have witnessed a rapid increase in litigation in Russia, in all spheres of the law. In 2014, for example, the courts of general jurisdiction in Russia considered more than 12.5 million civil and administrative cases compared to 9 million cases in the same category in 2007.

These increases in general litigation require nuanced explanation, and they can be attributed to a number of causes. In more official circles, it is widely claimed that increasing litigation is the result of the improved effectiveness and quality of the judicial system (Niyesov and Petukhov 2011: 64), of the expansion of legal protection for basic rights (Fokov 2007:2), and of increasing

91 Rules of Drafting of Normative Legal Acts of the Federal Executive Authorities and their State Registration, approved by the Government Decree No. 1009 of 13 August 1997.

See the classic account in Tate (1995: 27). 
accessibility and efficiency of the judicial system. ${ }^{93}$ In addition, increasing litigation can be linked to a targeted series of public policies, aimed at increasing public access to the law and at creating incentives for citizens to resolve individual disputes by formal means. The 1991 Concept of Judicial Reform had in fact already recognized that it was essential 'to move the court closer to the people, to facilitate access to justice,' and to ensure openness of legal databases and court decisions. Increased access to courts was then one of the prime concerns of federal programs for reforming the judicial system introduced in 2002, 2006, and 2013, ${ }^{94}$ reflecting the wider endeavour to eradicate shadow justice and legal nihilism from the political system (Barschevsky and Torkunov 2012). In important cases, the Supreme Court has also ruled that the need to ensure openness and transparency of court proceedings is a corollary of the guarantee of the right to a fair trial in the ECHR. ${ }^{95}$ As a result of these processes, between 2008 and 2011 the number of cases in regional courts of general jurisdiction (comprising $90 \%$ of all courts in Russia) that have been made available for public access via open databases increased from 5,500 rulings to 211,00o rulings. Alongside this, perhaps the most important incentive for general litigation is that court fees have been deliberately kept low (an equivalent of circa 4.6 USD per case).$^{96}$ Whatever their causes, the increase in the number of cases brought before the courts conflicts with more widespread accounts of Russian society as a society defined by a 'meagre demand' for law (Hendley 1999: 92).

Very notable for discussion of the secondary constitutional role of courts, however, is the fact that recent years have witnessed a significant rise in certain quite particular areas of litigation. Indeed, the increasing litigiousness of Russian citizens is especially striking in the field of administrative litigation or, to use the terminology of the Russian Administrative Litigation Code,

93 Russian National Congress of Judges, Resolution of the VI Session 'On the Current State of Justice in the Russian Federation and the Prospects of its Improvement', 2 December 2004.

94 Government Decrees No. 805 of 20 January 2001, No. 583 of 21 September 2006, No. 1406 of 27 December 2012.

95 See Supreme Court of the Russian Federation (2012). Plenum Ruling No. 35 of 13 December 2012 'On the Openness and Transparency of Judicial Proceedings and Access to Information on the Activities of Courts'. Rossiiskaya Gazeta 292, 19 December 2012. Also, recently, ECtHR found a violation of Article 6 for lack of open access to court judgments in Russia, see Malmberg and Others $v$ Russia (Judgment of 15 January 2015, Applications No. 23045/05, 21236/o9, 17759/10 and 48402/10).

96 The fee was first set in 2000 through enactment of the Tax Code (2000) (Art 333.19). Since then it has increased, very slightly, to 300 Rubles (as of 2016). 
in 'cases arising from administrative or other public law relations'. ${ }^{97}$ Over the past fifteen years, the number of normative legal acts issued by federal, regional, and municipal authorities that are invalidated by courts as a result of judicial review initiated by individuals or companies has averaged 2,700 acts per year. This litigation reached a peak in 2007 , when 4,800 acts were successfully challenged. Later years showed a stable downward trend, while maintaining a similar success rate of $60-63 \%$ of applications. In addition, this same period has seen a significant increase in the number of claims brought by individuals or private companies against state administrative bodies for illegal actions or lack of action. During the period of economic growth and political stability in the years 2002-2006, the number of such claims slowly decreased, reaching its lowest point of 42,00o claims considered in 2006. Then, there followed three years in which claims slowly increased again, eventually soaring to 145,000 claims in 2011 . This was the year which saw the beginning of numerous public protests against allegedly falsified Duma and presidential elections, and in which Putin was nominated President for the third time after a four-year break. Importantly, the success of such antigovernment claims began to decline after 2011, so that by 2014 applicants were successful in only $47 \%$ of cases against illegal actions of the state, compared to $73 \%$ in 2002.

In discussing rises in public-law litigation in Russia, of course, some caution is required. Evidence suggests that success rates for litigants in politically sensitive domains, such as cases concerning public protest and protection of political organizations, are lower than the average success rate. For example, of the 120 cases heard by the Supreme Court challenging the liquidation of political parties for violation of the Russian legislation only $18 \%$ had a favorable outcome for the applicant. Between 2007 and 2014 the average success rate of claims concerned with violations of electoral rights remained stable $(27 \%)$. It peaked to $38 \%$ in 2011 (the year of Duma elections) and reached its lowest in $2013(18 \%)$ as the aftermath of the 2012 presidential elections. The average number of claims remained at 3,700 claims per year level, with only a slight

97 This category includes: (1) recovery of damages caused by unlawful actions committed during criminal investigation, prosecution and trial; (2) suspension and termination of activities of public associations and political parties; (3) involuntary hospitalization of a citizen in a psychiatric hospital and compulsory psychiatric examination; (4) compensation awarded for the violation of the right to a trial in a reasonable time: (5) challenges to normative acts of municipal, regional or federal bodies violating federal legislation; (6) complaints about illegal actions (or inaction) of state and municipal officials, including violations of electoral legislation and other categories. 
variation during or immediately after the elections. Of the 900 cases heard by regional courts regarding administrative punishment for violation of the rules regarding participation in public gatherings almost 500 court decisions $(55 \%)$ upheld the administrative punishment for participants. ${ }^{98}$ Even in such cases, however, success rates for applicants against acts of government bodies are not negligible. ${ }^{99}$

These growth rates in litigation against public bodies in Russia can be imputed, most immediately, to rafts of legislation, adopted during Putin's presidency, which are designed to simplify, and even to stimulate, legal proceedings against public agencies. A key example of such legislation is the 2002 Civil Procedure Code, which, in Chapter 25, contains procedural guarantees for applications challenging actions and decisions of public authorities. Above all, however, these guarantees have been expanded in the Administrative Litigation Code of $2015,{ }^{100}$ which clearly reflects an intentional governmental strategy to facilitate litigation against bodies exercising public authority. Importantly, in fact, the 2015 Code was anticipated in one of Putin's post-election memoranda in 2012, in which he outlined his priorities for the development of the judicial system, directed towards the harmonization of public administration standards with international norms (Putin 2012). The explanatory note accompanying the draft for this Code expressly mentioned that the Code was intended to establish principles of administrative judicial process reflecting the Universal Declaration of Human Rights, International Covenant on Civil and Political Rights and ECHR, and taking into account best practices of administrative proceedings in other countries. ${ }^{101}$ Adoption of the Code was encouraged by the UN Special Rapporteur on the Independence of Judges after her country visit to Russia in 2013; she described the Code 'as one of the means to strengthen mechanisms to effectively fight corruption and ensure liability of state officials.' ${ }^{102}$ In this regard, it is important to note that legal regulations permitting challenges to actions and decisions

98 Search engine of the online public legal database www.consultant.ru.

99 For infringements of the right to protest in Russia see the ECtHR case Frumkin v. Russia (Application no. 74568/12, Judgment of 5 January 2016).

100 For comprehensive overview of the debate on adoption of the Code see the collection edited by Solovey (2014).

101 Draft Administrative Litigation Code and Related Federal Laws are submitted to the State Duma, kremlin.ru, 27 March 2013.

102 Special Rapporteur on the independence of judges and lawyers, Report on the Mission to the Russian Federation, A/HRC/11/41/Add.2 of 30 April 2014, para. 127. 
of state authorities have actually been in place since $1993 \cdot{ }^{103}$ In fact, such provisions existed even earlier, in RSFSR procedural codes and substantive legislation. ${ }^{104}$ Currently, on average 300,000 judgments in this category are passed annually, with a stable $84-91 \%$ success rate for applicants. Despite this, however, prior to 2015, anti-government litigation was not regulated by a special body of law or a special sphere of legal practice, and the presumption that there was 'no clearly marked area of Russian law that could be referred to as anti-government litigation in the sense that is common for democratic countries' was widespread in doctrinal literature (Razumov 2005: 8). The 1993 Constitution (Art 118.2.) always identified administrative proceedings as an independent type of litigation, based on a special procedural law. ${ }^{105}$ Nonetheless, claims against state bodies, depending on the type of respondent, were normally resolved according to Civil, Criminal or Arbitration Procedure Codes, whose provisions for challenging state bodies' actions and decisions were somewhat fragmentary. ${ }^{106}$ Accordingly, the drafters of the 2015 Administrative Litigation Code wrote the Code because they thought it essential to create a separate procedural law for resolving administrative claims, to establish a comprehensive regulatory framework for persons wishing to file suits against the state, and, in so doing, to fulfill constitutional provisions for administrative litigation which had not previously been translated into legislation. ${ }^{107}$

On this basis, it appears quite evident that in Russia administrative litigation is specifically solicited by governmental authorities. Self-evidently, this

103 Law of the Russian Federation No. 4866-1 of 27 April 1993 'On Appealing Actions and Decisions Violating Rights and Freedoms of Citizens' (void since 15 September 2015).

104 Chapters 23 and 24 of RSFSR Civil Procedure Code of 11 June 1964 (protection of voting rights and challenging actions of public authorities, respectively); Chapter 19 of RSFSR Criminal Procedure Code of 27 October 1960 (challenging decisions of public authorities operating in criminal proceedings); Chapter 22 of the RSFSR Code on Administrative Offenses of 20 June 1984 (challenging decisions of public authorities operating in administrative proceedings); USSR Law of 30 June 1987 'On the Procedure for Appealing to Courts Unlawful Actions of Officials which Violate the Rights of Citizens', revised on 2 November 1989. For an overview of this legislation see Solomon (2004: 555).

105 Chairman of the Constitutional Court Valeriy Zorkin's speech at the vin Russian National Congress of Judges, 18 December 2012.

106 These are Civil Procedure Code (2002) Chapters 24, 25, 26; Criminal Procedure Code (2001) Chapters 16 and 19; Code of the Russian Federation on Administrative Offenses (2001) Chapter 30; Arbitration Procedure Code (2002) Chapter 24.

107 Explanatory Note to the Draft Administrative Litigation Code No. 24696o-6 (www.duma .gov.ru). 
can lead to open condemnation of public bodies. Yet, filing of suits against public institutions is deliberately encouraged, partly through assimilation of international standards regarding administrative accountability. In general, we might speculate that litigation is encouraged because it contributes to wider governmental policies of state solidification. At one level, increasing litigation clearly reinforces the material reality of the constitution in society, and it brings actors in society, through the constitution, into a more immediate relation to the political system. To this degree, the encouragement of litigation might be linked to the fact that it increases popular legal consciousness, ensuring that citizens seek redress in their grievances, not through informal justice, but through norms and procedures formally bound to the state, and, as a result, binding citizens more directly to the state. At a different level, incentivization of administrative litigation also assumes importance in the context of centre-region relations, and litigation is promoted, again in line with international standards, because it helps to establish legal uniformity between centre and regions, and to connect public agencies in the regions more directly to the central state. Notably, the rising quantity of litigation in Russia, especially litigation against public bodies, necessarily curtails the autonomy of regional institutions (historically inclined to high levels of corruption and patrimonialism), and it brings these institutions more completely under the authority of central government. We can observe this, for example, in the fact that in litigation against actions and decisions of state bodies the success rate of appeals to superior courts is very high. In 2014, appeals against lower-court decisions occurred in approximately $35 \%$ of cases, and approximately $25 \%$ of such appeals met with success. ${ }^{108}$ In this respect, administrative litigation clearly provides a mechanism in which higher courts can oversee lower courts, and in which public agencies at all levels of society can be tied more effectively to the national legal/political system. Overall, therefore, litigation appears to be officially stimulated as an activity that stabilizes the position of central government institutions in society, brings society into convergence around the government, and, above all, extends the presence of the constitution (and thus also the state) into different parts of society.

Whatever their motivation, the government's broader policies in this regard have led to a significant change in the public use of law, stimulating quite extensive legal mobilization in both civil and administrative litigation. Most importantly, litigation and the incentivization of litigation have acquired a

108 Annual judicial statistics report for 2014, Forms 2 and 7, line 62, available from: Judicial Department of the Supreme Court [Online] Available from: http://cdep.ru/index .php?id=79\&item=2884 [Accessed: 29 September 2016]. 
powerful constituent role, and they manifestly perform processes of secondary constitutionalization, linking the constitution to legal demands across society. ${ }^{109}$ As discussed, litigation has led to a hardening of legal norms around the political system; it has intensified the accountability of public bodies; it has created stricter and more clearly defined obligations for government institutions; it has widened opportunities for individuals to seek redress for human rights violations. In each respect, individual citizens have been able to exercise de facto constituent agency, using litigation to cement the authority of constitutional norms at the intersection between government and society. In fact, this is particularly evident through public interest litigation in Russia, a type of litigation which commonly possesses clear constitutional implications. ${ }^{110}$ As a general rule, a large proportion of such cases - that is, cases filed in the 'interests of unidentifiable number of persons' - are brought to courts by public prosecutors, whose main role in contemporary Russia is to ensure compliance with the law of all actions and decisions of public bodies. ${ }^{111}$ The number of individual claims considered by prosecutors is constantly growing. In 2015, it reached almost 4.5 million claims, ${ }^{112}$ a number exceeding individual claims against state bodies in courts by 14 times. More than $70 \%$ of individual claims filed with the procuracy were considered on merits. Of these, nearly 417 thousand claims were satisfied by the prosecutors themselves and 770 thousand were resolved by courts, with a $92 \%$ success rate. Although the number of public interest litigation cases filed by the prosecutors in courts has been decreasing over the last five years, the quantity still remains significant. The mobilization of citizens through litigation thus appears as a particularly powerful dynamic for secondary constitutionalization. This dynamic of secondary constitutionalization, moreover, imprints distinctive accountability structures on the Russian political system, in which legal actions form a primary source of normative obligation.

109 In fact, if we observe use of law as a measure of the linkage between state and society, the reach of the state into society has been both extended and simplified through Putin's reforms. For similar reflections in different contexts see Black (1973); Giles and Lancaster (1989).

110 See classic discussion of this point in Indian case law, notably in S. P. Gupta vs President of India and ors, on 30 December, 1981 (Bhagwati J).

111 Federal Law No. 2202-1 of 17 January 1992 ‘On Procuracy in the Russian Federation’, Art 1.

112 Official statistics of the Procuracy, available from: http://www.genproc.gov.ru/stat/data/ [Accessed 29 September 2016]. 


\subsection{Secondary Constitutionalization 4: Changing Patterns of Legal Argument}

These processes of constitutionalization through litigation in Russia are not only linked to the simple volume of litigation passing through the courts. In addition, they are also visible in the content of legal arguments and jurisprudential reasoning in cases heard by the courts, which have in some cases created new legal principles and even new grounds for administrative action. Notable in this process, above all, is the fact that the openness of the legal system to international law has promoted the evolution of new lines of jurisprudence, leading to more favourable outcomes for applicants, which have in turn promoted more robust controls on public authorities and thus assumed clearly secondary-constitutional implications.

For example, the growing volume of administrative litigation has led to a general assimilation of international human rights law in domestic jurisprudence in Russia, a fact which has manifest constitutional results. This change can be identified in the more consistent application by courts of concepts derived from ECtHR jurisprudence, such as humanitarian considerations, priority of human dignity, ${ }^{113}$ balance of public-private interests, legal certainty and predictability of legal regulation (Starzhenetskiy 2013: 65). The concept of 'legitimate expectations' (or 'reasonable expectations' in arbitrazh practice) has also become an established principle of Russian jurisprudence. ${ }^{114}$ In fact, this principle was first introduced into Russian law by applicants making express reference to ECtHR jurisprudence, and it became widely used on its own merits through a ruling of the RCC. ${ }^{115}$ A further example can be identified in the adoption of a number of international law concepts by the Russian arbitrazh courts for resolving commercial disputes: for example, jurisdictional dispute management, preliminary interim measures immunities, and forms of alternative dispute resolution (Neshataeva 2013: 5).

Changing patterns of judicial argument can also be illustrated by the move towards use of judicial precedent, which can be clearly identified as a major recent trend in the Russian legal system. ${ }^{116}$ This is clearly caused by increasing reference in Russian courts to ECtHR jurisprudence, which is expressly

\footnotetext{
113 In RCC Ruling No. 8-P of 27 March 2012 the concept of human dignity was used to define the necessity to publish federal laws on ratification of fixed-term international treaties.

114 Higher Arbitrazh Court Plenum Ruling No. 17 of 14 March 2014 'On Some Issues Related to Lease Agreements of Redemption'.

115 RCC Ruling on Merits No. 29-P of 20 December 2011.

116 See, among others, Matveev (2002: 84); Eckstein (2004: 36); Yershov (2006: 164, 166, 236, 249, 254); Zorkin (2007: 125).
} 
encouraged, if not enforced, by the government. ${ }^{117}$ There remains an ongoing theoretical dispute as to whether judicial precedent is a source of law in Russia. ${ }^{118}$ Previously, the precedential quality of any judicial decisions, apart from guiding explanations of the Supreme Court Plenum, had been denied. ${ }^{119}$ However, recent trends have led to new approaches to use of precedent in doctrine, ${ }^{120}$ in policy, ${ }^{121}$ and in practice. ${ }^{122}$ In particular, it is now becoming clear that the conventionally binding legal force of ECtHR judgments needs to be incorporated within the Russian legal system, and that these judgements have to be accorded precedential authority (Granat 1998: 12; Zverev 2006: 17-22). Notably, use of precedent heightens the de facto legislative powers of the courts. Moreover, it consolidates the wider autonomy of the judicial system; it means that courts increasingly refer to internal principles to sustain their rulings (Pomeranz and Gutbrod 2012: 27, 29). In fact, the widening use of precedent is clearly related to the broader consolidation of administrative law, and it plays an important role in stimulating anti-government litigation. In telling fashion, the last Chairman of Highest Arbitrazh Court, Anton Ivanov, who made openness of the judiciary a major goal during his tenure (Veletminsky and Kulikov 2005), announced at a meeting with judges of the Constitutional Court that he had identified 'a sharp increase in complaints with reference to published online judicial acts'. This can be taken to imply that growing acceptance of precedential authorities increased the willingness of citizens to pursue causes through the courts (Ivanov 2010), further augmenting the constitutional force of legal actions, especially litigation.

117 Supreme Court of the Russian Federation Plenum Ruling No. 5 of 10 October 2003 'On Application by the Courts of General Jurisdiction of the Universally Recognized Principles and Norms of International Law and International Treaties of the Russian Federation'.

118 For the summary of the dispute see Justices of the Constitutional Court Zorkin (2004); Aranovskiy and Knyazev (2013); Gadjiyev (2013).

119 On their legal status see, in much detail Burkov (2010: 87-125).

120 See, among many others, Usanov (2008: 20); Pomeranz and Gutbrod (2012: 16); Glukhoyedov and Guschina (2013: 80).

121 Council on Development of Civil Society and Human Rights under the President of the Russian Federation: Permanent Commission on Precedent Cases [Online] 9 October 2015. Available from: http://president-sovet.ru/presscenter/news/read/2770/ [Accessed 29 September 2016].

122 See, for example, Fourth Arbitration Court of Appeal, Resolution of the Presidium No. 17 of 29 June 2009 'Methodological Guidelines on the Study and Generalization of Court Practice and Other Analytical Activities'. [Online] Available from: http://www.4aas .arbitr.ru/node/911 [Accessed 29 September 2016]. 
Particularly important in this respect is the fact that the concept of proportionality has also become an established component of Russian jurisprudence. To be sure, use of proportionality reasoning by Russian courts is still subject to certain caveats. ${ }^{123}$ Nonetheless, it is becoming less frequent for courts simply to justify limitations on constitutional rights, especially when reference is made to international law. Instead, courts now commonly apply considerations of proportionality to assess collisions between public interests and private rights. Some scholars even suggest that the principle of proportionality should be set out in federal law to ensure that the 'nuclear content' of this principle is guaranteed as binding, not only on courts, but also on the legislative and executive branches (Cherepanov 2014: 109). When assessing collisions between equally protected constitutional values, further, the courts usually resolve proportionality questions by according particular emphasis to humanitarian considerations; this also has an obvious ECtHR background. This trend is best exemplified by administrative deportation and denied entry cases. More than half of the 92 Supreme Court cases on administrative deportation between 2005 and 2014 cite Art 8 ECHR to overturn a lower court's decision to deport foreign citizens from Russia. Notably, the Supreme Court has emphatically stipulated that judges must apply proportionality considerations in deportation cases, showing due regard for Art 8 ECHR. ${ }^{124}$

Overall, these changing patterns of legal argument have led to notable, constitutionally transformative outcomes in the Russian legal/political system. In particular, the reception of new principles of jurisprudence now facilitates legal redress for rights violations, it creates a sharper diction of accountability and imposes stricter normative standards on governmental administrative bodies, and it makes it easier for legal professionals and citizens to evaluate public acts through a constitutional lens. More generally, these changes in judicial reasoning also clearly demonstrate that the Russian constitution has entered a distinctive and partly autonomous formative path, and, in this respect, legal/judicial practices act as primary sources of the material constitution. Above all, legal exchanges, concentrated around acts of litigation, have established quite distinctive principles of accountability, asymmetrically weighted towards the control of government acts by persons and institutions drawing authority, not from an obvious political mandate, but from the law alone.

\footnotetext{
123 RCC Ruling on Merits No. 8-P of 28 June 2007.

124 Supreme Court of the Russian Federation Plenum Ruling No. 5 of 24 March 2005 'On Some Issues Arising from Application of the Code on Administrative Offenses by Courts'. Para. 23.1.
} 
To understand the sociological basis of the Russian Constitution, we need to observe the Constitution as the evolving result of an aggregate of sociolegal processes. Moreover, we need to look beyond more conventional patterns of participation, conventional modes of collective motivation, and even conventional categories of constitutional personality to construct the social practices that shape the constitutional order. Standard accounts of the Russian Constitution surely have their own validity in claiming that informal practices predominate over rule-bound order, and that the Constitution is rendered socially irrelevant by this fact; it remains the case that some questions fall beyond the reach of the law. In some respects, however, the Russian Constitution is locked into cycles of societal norm construction. At one level, the Constitution is socially determined by the role that it plays in a longerterm dynamic of legal systematization and judicial reform. This began during the collapse of the Soviet Union, and it was substantially intensified by Putin from 2000 onwards, owing to his use of the Constitution as an instrument for stabilizing governmental power. At a different level, the constitution is socially determined by the fact it opens the political system to distinct patterns of norm-forming agency in society, usually expressed through litigation. In both respects, the Constitution is constructed in relatively autonomous fashion, and the present-day political system of Russia has been shaped by four relatively autonomous processes of secondary constitutional norm formation. As a result, the legal-constitutional order of Russia is defined, in part, by the following characteristics: 1) increasingly high authority of international norms; 2) extensive judicial control of the acts of public bodies; 3) high volumes of litigation, including increasing litigation against public bodies; 4) changing contours of legal argument.

In view of these processes, we can conclude, first, that the Russian Constitution, in its factual or material form, has entered a relatively autonomous formative trajectory. Some aspects of the constitutional order are evidently politically dictated, but many of its features have developed beyond the scope of original political directives. In many cases, the material constitution evolves dialectically; legal measures introduced by the government to shore up its own authority have, in some cases, resulted in relatively robust constitutional constraints on public institutions. In light of these processes, second, it becomes possible to conclude that the Russian political system, although limited in its provisions for political accountability is marked by a higher level of legal accountability. More importantly, it is shaped by a relatively high level 
of legal mobilization, which expands and entrenches the accountability functions performed by the legal system generally. For this reason, it is becoming possible to characterise the Russian constitutional order as one marked by asymmetrical, or even paradoxical, emphasis on legal inclusion and legal accountability, at times to the detriment of conventional structures of political inclusion and accountability. One result of these tendencies, clearly, is that in contemporary Russia the evolution of a relatively robust constitutional order might be seen as standing in for full competitive democracy. That is, constitutional instruments for formalizing the legal rights of citizens may, in some respects, be compatible with, or even at times support, governmental practices not anchored in respect for principles of political democracy. There are of course many historical examples of states that have promoted formal constitutionalism as a mechanism, not primarily for enhancing democracy, but rather for the more technical purpose of increasing the proximity between the governmental executive and persons in different parts of national society (a process often called state building or nation building). ${ }^{125}$ It may be legitimate, in part, to associate contemporary Russia with patterns of constitutionalism of this kind. One further result of these tendencies, however, is that the factual construction of individual constitutional rights by the government is in itself not negligible, and the web of constitutional practices discussed above creates a real material setting for the exercise of government power, with materially meaningful legal articulations between citizens and the state. In each respect, it is clear that the Russian constitution is not marked by any full disengagement from society. On the contrary, it is formed through several different modes of social practice, closely linked to processes of litigation, and it is integrally correlated with society on that basis.

\section{Acknowledgements}

Research for this article was funded by the European Research Council (Advanced Grant 323656-STC).

125 Many states in the later nineteenth century, especially, but not exclusively, in Europe, were constructed around this principle. For discussion of different cases see Rudelle (1982: 289); Ghisalberti (2000: 189); Beckmann (1957). The classic example of this is Imperial Germany. See discussion in Mommsen (1990). 


\section{References}

Andreeva, G. N. 2013. "The Sociological Dimension of Constitutional Law as an Area of Science", pp. 109-120. In E. V. Alferova ed., Modern Sociology of Law: A Collection of Scientific Papers, Moscow: RAN INION.

Antonov, M. 2014. "Conservatism in Russia and Sovereignty in Human Rights", Review of Central and East European Law, 39: 1-40.

Aranovskiy, K. and Knyazev, S. 2013. "The Destiny of Judicial Precedent in RomanGermanic Law", Zhurnal konstitutsionnogo pravosudiya, 4 (34): 30-39.

Baranov, V. 2002. "On the Shadow Law", Novaya Pravovaya Misl, 1: 13-20.

Barschevsky, M. and Torkunov, A. 2012. "A Judge for Himself. Penalties for "Telephone Justice. Control over Expenses in a Package of Proposals for Reform of the Third Power", Rossiyskaya Gazeta, 14 February.

Baudenbacher, C. 2003. "Foreword: Globalization of the Judiciary", Texas International Law Journal, 38: 397-472.

Beckmann, G. G. 1957. The Making of the Meiji Constitution. The Oligarchs and the Constitutional Development of Japan, 1868-1891, Westport: Greenwood.

Black, D. 1973. "The Mobilization of Law", The Journal of Legal Studies, 2(1): 125-149.

Borisov, G. A. 2002. "Exploring the Potential of the Constitution: Problems and Prospects", RAYUN Proceedings, 2: 195-200.

Burbank, J. 2006. "An Imperial Rights Regime: Law and Citizenship in the Russian Empire", Kritika: Explorations in Russian and Eurasian History, 7(3): 397-431.

Burger, E. S. and Holland, M. 2008. "Law as Politics: The Russian Procuracy and Its Investigative Committee", Columbian Journal of European Law, 2: 142-193.

Burkov, A. 2010. Convention on Protection of Human Rights in Russian Courts, Moscow: Wolters Kluwer.

Carothers, T. 2002. "The End of the Transition Paradigm", Journal of Democracy, 13(1): $5^{-21 .}$

Chandler, A. 2014. "Citizenship, Social Rights and Judicial Review in Regime Transition: The Case of Russia", Democratization, 21(4): 743-766.

Chebankova, E. A. 2010. Russia's Federal Relations. Putin's Reforms and Management of the Regions, London: Routledge.

Cherepanov, V. 2014. "On the Draft Federal Law 'On Normative Acts in the Russian Federation”, Zhurnal rossiyskogo prava, 3: 105-111.

Dobrynin, N. M. 2009. "Constitutionalism in Russia's Recent History: Its Potential and Opportunities", Gosudarstvo i pravo, 2: 5-8.

Easter, G. M. 1996. "Personal Networks and Postrevolutionary State Building: Soviet Russia Reexamined”, World Politics, 48(4): 551-578.

Easter, G. M. 2008. “The Russian State in the Time of Putin", Post-Soviet Affairs, 24(3): 199-230. 
Eckstein, K. 2004. "Recognition of General Principles of Law. The Doctrine of the Rule of Law State", pp. 36-39. In V. K. Bobrov, S. V. Kabyshev, M. A. Mityukov and A. V. Sycheva, eds., The Generally Recognized Principles and Norms of International Law, International Treaties in the Practice of Constitutional Justice, Moscow: International Relations.

Ferejohn, J. 2002. "Judicializing Politics, Politicizing Law", Law and Contemporary Problems, 65(3): 41-68.

Fish, M. S. 2005. Democracy Derailed in Russia. The Failure of Open Politics, Cambridge: Cambridge University Press.

Fokov, A. 2007. "Russian Academy of Justice (Academic Hour)", Rossiiskiy sudia 9: 2-3.

Gadjiyev, G. 2013. "Methodological Problems of the 'Precedent Revolution' in Russia", Zhurnal konstitutsionnogo pravosudiya, 4 (34): 5-8.

Garcelon, M. 2005. Revolutionary Passage: From Soviet to Post-Soviet Russia, 1985-200o, Philadelphia, PA: Temple University Press.

Gelman, V. 2004. "The Unrule of Law in the Making: The Politics of Informal Instituiona Building in Russia", Europe-Asia Studies, 56(7): 1021-1040.

Gelman, V. 2015. Authoritarian Russia. Analyzing Post-Soviet Regime Changes, Pittsburgh: Pittsburgh University Press.

Ghisalberti, C. 2000. Storia costituzionale d'Italia 1848-1948, Rome-Bari: Laterza.

Giles, M. W. and Lancaster, T. D. 1989. "Political Transition, Social Development, and Legal Mobilization in Spain”, The American Political Science Review, 83(3): 817-833.

Gill, G. 2015. Building an Authoritarian Polity, Cambridge: Cambridge University Press.

Glukhoyedov, M. and Guschina, N. 2013. "Judicial Precedent in the Russian Legal System: History, Theory, Practice", Sovremennoye parvo, 2: 79-84.

Granat, N. 1998. "Sources of Law", Yurist, 9: 6-12.

Grzymala-Busse, A. and Luong, P. J. 2002. "Reconceptualizing the State: Lessons from Post-Communism", Politics and Society, 30(4):529-554.

Habermas, J. 1962. Strukturwandel der Öffentlichkeit. Untersuchungen zu einer Kategorie der bürgerlichen Gesellschaft, Frankfurt am Main: Suhrkamp.

Hale, H. E. 2006. Why not Parties in Russia? Democracy, Federalism and the State, Cambridge: Cambridge University Press.

Hale, H. E. 2011. "Formal Constitutions in Informal Politics: Institutions and Democratization in Post-Soviet Eurasia", World Politics, 63:581-617.

Hale, H. E. 2015. Patronal Politics. Eurasian Regime Dynamics in Comparative Perspective, Cambridge: Cambridge University Press.

Hanson, P. and Teague, E. 2005. "Big Business and the State in Russia", Europe-Asia Studies, 75(5): 657-68o.

Hassner, P. 2008. "Russia's Transition to Autocracy", Journal of Democracy, 19(2): 5-15.

Henderson, J. 2011. The Constitution of the Russian Federation: A Contextual Analysis, Hart. 
Hendley, K. 1999. "Rewriting the Rules of the Game in Russia: The Neglected Issue of the Demand for Law", East European Constitutional Review, 8: 89-95.

Hendley, K. 2009. “'Telephone Law' and the 'Rule of Law': The Russian Case”, Hague Journal on the Rule of Law, 1(2): 241-262.

Hendley, K. 2011. "Varieties of Legal Dualism: Making Sense of the Role of Law in Contemporary Russia”, Wisconsin International Law Journal, 29: 233-262.

Hendley, K. 2013. "The Puzzling Non-Consequences of Societal Distrust of Courts: Explaining the Use of Russian Courts", Cornell International Law Journal, 45:517-567. Hendley, K. 2015. "Justice in Moscow?", Post-Soviet Affairs, 13(1):1-21.

Hirschl, R. 2000. "The Political Origins of Judicial Empowerment through Constitutionalization: Lessons from Four Constitutional Revolutions", Law \& Social Inquiry, 25(1): 91-149.

Hirschl, R. 2007. "The New Constitutionalism and the Judicialization of Pure Politics Worldwide", Fordham Law Review, 75: 721-753.

Hyde, M. 2001. "Putin's Federal Reforms and their Implications for Presidential Power in Russia", Europe-Asia Studies, 53(5): 719-743.

Ivanov, A. 2010. "Chairman of the Higher Arbitration Court of the Russian Federation: Speech at the Third Senate Readings at the Constitutional Court of the Russian Federation 'On the Precedent', Arbitr.ru, 19 March.

Kahn, J. 2000. "The Parade of Sovereignties: Establishing the Vocabulary of the New Russian Federalism", Post-Soviet Affairs, 16(1): 58-89.

Kahn, J. 2002. Federalism, Democratization, and the Rule of Law in Russia, Oxford: Oxford University Press.

Kahn, J., Trochev, A. and Balayan, N. 20og. "The Unification of Law in the Russian Federation", Post-Soviet Affairs, 25(4): 310-346.

Komarova, V. 2014. The Mechanism of Direct Democracy in Modern Russia (Systems and Procedures), Moscow: Direct-Media.

Konitzer, A. 2005. Voting for Russia's Governors. Regional Elections and Accountability under Yeltsin and Putin, Baltimore: John Hopkins University Press.

Konitzer, A. and Wergren, S. K. 2006. "Federalism and Political Recentralization in the Russian Federation: United Russia as the Party of Power", Publius, 36(4): 503-522.

Ledeneva, A. 2006. How Russia Really Works. The Informal Practices that Shaped PostSoviet Politics and Business, Ithaca: Cornell University Press.

Ledeneva, A. 2008. “Telephone Justice in Russia”, Post-Soviet Affairs, 24 (4): 324-350.

Levakin, I. V. 2016. "Evolution of the Constitution and Sociology of the Russian Legal System", The Law and Modern States, 1: 17-34.

Levitsky, S. and Way, L. 2002. "The Rise of Competitive Authoritarianism", Journal of Democracy, 13(2): 51-65. 
Loughlin, M. 2010. Foundations of Public Law, Oxford: Oxford University Press.

Luhmann, N. 1980. Rechtssoziologie, Opladen: Westdeutscher Verlag.

Luhmann, N. 1993. Das Recht der Gesellschaft, Frankfurt am Main: Suhrkamp.

Makarenko, B. I. 2012. "The Post-Soviet Party of Power", Russian Politics and Law, 50(1): $54-83$.

Maliy, A. F. 2014. "Modification of the Constitution: Expectations and Opportunities", RAYUN Proceedings, 14, Vol. 1.: 613-616.

Matveev, D. 2002. Russia as a Member of the Council of Europe: The Implementation of Treaty Obligations, Moscow: Publishing House I k 'Catalogue'.

Mazmanyan, A. 2015. "Judicialization of Politics: The Post-Soviet Way", International Journal of Constitutional Law, 13(1): 200-218.

McFaul, M. 1995. "State Power, Institutional Change, and the Politics of Privatization in Russia", World Politics, 47(2): 210-243.

Medvedev, D. 2008. "Inauguration Speech", Kremlin.ru, 7 May.

Medvedev, D. 2013. "The Constitution, Functions of the Government of Russia and the Effective Management Technologies”, Zakon, 12: 32-40.

Mitukov, M. A. 2007. "Modern Trends in the Development of Regional Constitutional Justice (Sociological Perception)", Konstitutsionnoye i munitsipalnoye pravo, 14: 19-23.

Mommsen, W. J. 1990. Der autoritäre Nationalstaat. Verfassung, Gesellschaft und Kultur im deutschen Kaiserreich, Frankfurt am Main: Fischer.

Moraski, B. 2006. Elections by Design. Politics and Patronage in Russia's Regions, DeKalb: Ill.: Northern Illinois University Press.

Morgan-Jones, E. 2010. Constitutional Bargaining in Russia, 1990-93. Institutions and Uncertainty, London: Routledge.

Neshataeva, T. 2013. Judgments of the European Court of Human Rights: Novelties and Impact on the Legislation and the Law-Application Practice, Moscow: Norma: Infra-M.

Niyesov, V. and Petukhov, N. 2011. "The Importance of the Plan to Create an Interregional Target Program Aimed at Establishing Cross-Institutional System of Information and Methodology Supply for Advanced Training of the Justices of the Peace and Court Staff", Rossiiskoye pravosudiye, 2(58): 64-69.

Ovsepyan, Zh. I. 2013. "Constitutional Economics; Constitutional Political Science; Constitutional Sociology - as New, Interdisciplinary Areas of Research in Constitutional Law", Scientific Notes of the Faculty of Law, 26 (36): 10-22.

Petrone, L. 2011. "Institutionalizing Pluralism in Russia: A New Authoritarianism?", Journal of Communist Studies and Transition Politics, 27(2): 166-194.

Pistor, K. 2002. "The Demand for Constitutional Law", Constitutional Political Economy, 13: $73-87$.

Pomeranz, W. and Gutbrod, M. 2012. "The Push for Precedent in Russia's Judicial System", Review of Central and East European Law, 37: 1-30. 
Putin, V. 2000. "Open Letter from Vladimir Putin to the Russian Voters", Kommersant, 32. Putin, V. 2012. "Democracy and the Quality of the State", Kommersant, 6 February.

Quigley, J. 1990. "Law Reform and the Soviet Courts", Columbia Journal of Transnational Law, 28: 59-75.

Razumov, S. 2005. "Application of International Law in the Administration of Criminal Justice", pp. 7-13. In Yu. Solovey, ed., The Use of International Law in the Work of Courts and Law Enforcement Bodies of the Russian Federation. Proceedings of a Research-Meets-Practice Conference in Omsk, 24 February 2005, Omsk: Publishing House of Omsk Law Institute.

Remington, T. 2000. "The Evolution of Executive-Legislative elations in Russia since 1993”, Slavic Review, 59(3): 499-520.

Remington, T. 2008. "Patronage and the Party of Power: President-Parliament Relations under Vladimir Putin", Europe-Asia Studies, 6o(6): 959-987.

Reuter, O. J. 2010. “The Politics of Dominant Party: United Russia and Russia's Governors", Europe-Asia Studies, 62(2): 293-327.

Roberts, S. P. 2012. Putin's United Russia Party, London: Routledge.

Robertson, G. B. 2011. The Politics of Protest in Hybrid Regimes. Managing Dissent in Post-Communist Russia, Cambridge: Cambridge University Press.

Rose, R. 1995. "Russia as an Hour-Glass Society: A Constitution without Citizens", East European Constitutional Review, 4: 34-42.

Ross, C. 2009. Local Politics and Democratization in Russia, London: Routledge.

Rudden, B. 1994. "Civil law, Civil society and the Russian Constitution", Law Quarterly Review, 110: 56-83.

Rudelle, O. 1982. La République absolue. Aux Origines de l'instabilité constitutionelle de la France républicaine 1870-1889, Paris: Publications de la Sorbonne.

Sakwa, R. 2008. "Putin and the Oligarchs", New Political Economy, 13(2): 185-191.

Sakwa, R. 2010. "The Dual State in Russia”, Post-Soviet Affairs, 26(3):185-206.

Sakwa, R. 2011. The Crisis of Russian Democracy. The Dual State, Factionalism and the Medvedev Succession, Cambridge: Cambridge University Press.

Sakwa, R. 2012. "Party and Power: Between Representation and Mobilisation in Contemporary Russia", East European Politics, 28(3): 310-327.

Shakhrai, S. 2013. About the Constitution: The Basic Law as the Instrument of Legal and Socio-Political Transformation, Moscow: Nauka.

Shakhray, S. M. 2014. "On the Creative Potential of the Current Constitution of the Russian Federation", pp. 83-108. In V. D. Zorkin ed., Modern Constitutionalism: Challenges and Prospects: Proceedings of International Scientific-Practical Conference dedicated to the 2oth anniversary of the Constitution of the Russian Federation (St. Petersburg, 14-15 November 2013), Moscow: Norma.

Sharlet, R. 1977. "Stalinism and Soviet Legal Culture", pp 155-179. In R. C. Tucker, ed., Stalinism. Essays in Historical Interpretation, New York: Norton. 
Sharlet, R. 1999. "Constitutional Implementation and State-Building: Progress and Problems of Law Reform in Russia", pp. 81-10o. In G. Smith, ed., State-Building in Russia. The Yeltsin Legacy and the Challenge of the Future, Armonk, New York: Sharpe.

Sharlet, R. 2001. "Putin and the Politics of Law in Russia", Post-Soviet Affairs, 17(3): 195-234. Shlapentokh, V. 1996. "Early Feudalism - The Best Parallel for Contemporary Russia", Europe-Asia Studies, 48(3): 393-411.

Shlapentokh, V., Levita, R. and Loiberg, M. 1997. From Submission to Rebellion. The Provinces versus the Centre in Russia, Boulder, co.: Westview.

Shleifer, A. and Treisman, D. 2005. "A Normal Country: Russia After Communism”, Journal of Economic Perspectives, 19(1): 151-174.

Smith, G. B. 1996. Reforming the Russian Legal System, Cambridge: Cambridge University Press.

Solomon, P. H. 2004. "Judicial Power in Russia: Through the Prism of Administrative Justice", Law \& Society Review, 38(3): 549-581.

Solovey, Yu. 2015. Current Problems of Administrative Litigation. Proceedings of the Conference in Omsk, 28 November 2014, Omsk: Omsk Law Academy.

Starzhenetskiy, V. 2013. "International Courts and Transformation of National Legal Systems”, Mezhdunarodnoye pravosudiye, 3 (7): 64-77.

Tate, C. N. 1995. "Why the Expansion of Judicial Power?", pp. 27-38. In C. N. Tate and V. Torbjörn, eds., The Global Expansion of Judicial Power, New York: New York University Press.

Taylor, B. 2011. State Building in Putin's Russia: Policing and Coercion after Communism, Cambridge: Cambridge University Press.

Teitel, R. 2011. Humanity's Law, Oxford: Oxford University Press.

Thornhill, C. 2011. A Sociology of Constitutions. Constitutions and State Legitimacy in Historical-Sociological Perspective. Cambridge: Cambridge University Press.

Thornhill, C. 2016. A Sociology of Transnational Constitutions. Social Foundations of the Post-National Legal Structure. Cambridge: Cambridge University Press.

Thorson, C. L. 2012. Politics, Judicial Review and the Russian Constitutional Court, Basingstoke: Palgrave, 2012.

Tiunov, O. 2011. "International Law and Legal Positions of the Constitutional Court of the Russian Federation", Zhurnal rossiyskogo prava, 10: 82-96.

Tompson, W. 2002. "Putin's Challenge: The Politics of Structural Reform in Russia", Europe-Asia Studies, 54(6): 933-957.

Trochev, A. 2008. Judging Russia. Constitutional Court in Russian Politics 1990-2006, Cambridge: Cambridge University Press.

Trochev, A. 2009. "All Appeals Lead to Strasbourg? Unpacking the Impact of the European Court of Human Rights on Russia", Demokratizatsyia, 17(2): 145-178.

Trochev, A. 2012. "Suing Russia at Home", Problems of Post-Communism, 59(5): 18-34. 
Usanov, V. 2008. "Judicial Precedent: The Problems of Convergence into the Russian Legal System”, Novaya yustitsiya. Zhurnal sudebnykh pretsedentov, 1: 18-23.

Veletminsky, I. and Kulikov, V. 2005. "Goes to Court: Anton Ivanov Appointed Chief Arbitration Judge of Russia”, Rossiyskaya Gazeta 27 January.

Vorontsova, I. V. and Solovieva, T. V. 2010. Judgments of the European Court of Human Rights in civil litigation in Russia, Moscow: Wolters Kluwer.

Walker, E. W. 2003. Dissolution. Sovereignty and the Breakup of the Soviet Union, Lanham: Rowman and Littlefield.

wсіом (Russian Public Opinion Research Center) 2005. Local Authorities and Law Enforcement Officers - the Most Corrupt Public Institutions in Russia? Press release No 15o. Available from: http://wciom.ru/index.php?id=236\&uid=1058.

wсIOM (Russian Public Opinion Research Center) 2007. Report on the results of the Nationwide Mass Survey of Russian Citizens on the Topic: 'Assessment of the Activity of Courts in the Russian Federation. Available from: https://wciom.ru/database/ open_projects/otsenka_deyatelnosti_sudov_v_rossii/.

Weber, M. 1921. Wirtschaft und Gesellschaft. Grundriß der verstehenden Soziologie, Tübingen: Mohr.

White, S. 1990. Gorbachev in Power, Cambridge: Cambridge University Press.

Wortman, R. S. 2010. The Development of a Russian Legal Consciousness, Chicago: Chicago University Press.

Yakovlev, A. 2006. "The Evolution of Business-State Interaction in Russia: From State Capture to Business Capture", Europe-Asia Studies, 58(7): 1033-1056.

Yershov, V., ed. 2006. Autonomy and Independence of the Judicial Power of the Russian Federation, Moscow: Russian Academy of Justice, Jurist.

Zazdravnykh, I. 2010. "Some Practical Issues of Organization of the Work on Carrying Out Justice in Compliance with the European Standards in Belgorod Region", Rossiiskoye pravosudiye, 4 (48): 101-103.

Zhukov, V. N. 2012. "Change and Development as Categories of the Sociology of Law", Gosudarstvo i pravo, 11: 47-59.

Zorkin, V. 2004. "Apologia of the Westphalian System", Rossiya v Globalnoy Politike, 3: 18-25.

Zorkin, V. 2004. "Precedent Nature of Constitutional Court of the Russian Federation Rulings", Zhurnal rossiyskogo prava, 12: 3-9.

Zorkin, V. 2007. Russia and the Constitution in the XXI Century. View from Iliyinka, Moscow: Norma.

Zorkin, V. 2009. "Repeating the Past. Commemoration of the Sixteenth Anniversary of the Russian Constitution", Rossiyskaya Gazeta, 11 December.

Zorkin, V. 2011a. "Anniversary of the Constitutional Court: Speech at the Meeting Dedicated to the Twentieth Anniversary of the Constitutional Court", Rossiyskaya Gazeta, 27 October. 
Zorkin, V. 2011b. "The Constitutional Court in its Historical Context. Reflections on the Anniversary of the Constitutional Court", Rossiyskaya Gazeta, 28 October.

Zverev, D. 2006. "New Sources of Civil Procedural Law in the Light of the European Convention on Human Rights", pp. 17-22. In R. F. Kallistratova and M. A. Fokin, eds. The European Integration Process and the Development of the Civil Law in Russia. Collected Articles, Moscow: RAP. 